\title{
Recent Advances in Chiral Analysis of Proteins and Peptides
}

\author{
Marine Morvan 1,2,*iD and Ivan Mikšík 1,2,*(D) \\ 1 Institute of Physiology of the Czech Academy of Sciences, Vídeňská 1083, 14220 Prague, Czech Republic \\ 2 Department of Analytical Chemistry, Faculty of Chemical Technology, University of Pardubice, \\ Studentská 573, 53210 Pardubice, Czech Republic \\ * $\quad$ Correspondence: Marine.Morvan@fgu.cas.cz (M.M.); Ivan.Miksik@fgu.cas.cz (I.M.)
}

Citation: Morvan, M.; Mikšík, I.

Recent Advances in Chiral Analysis of Proteins and Peptides. Separations 2021, 8, 112. https://doi.org/ 10.3390 /separations 8080112

Academic Editor: Maria

Elizabeth Tiritan

Received: 8 June 2021

Accepted: 27 July 2021

Published: 29 July 2021

Publisher's Note: MDPI stays neutral with regard to jurisdictional claims in published maps and institutional affiliations.

Copyright: (c) 2021 by the authors. Licensee MDPI, Basel, Switzerland. This article is an open access article distributed under the terms and conditions of the Creative Commons Attribution (CC BY) license (https:// creativecommons.org/licenses/by/ $4.0 /)$.

\begin{abstract}
Like many biological compounds, proteins are found primarily in their homochiral form. However, homochirality is not guaranteed throughout life. Determining their chiral proteinogenic sequence is a complex analytical challenge. This is because certain D-amino acids contained in proteins play a role in human health and disease. This is the case, for example, with D-Asp in elastin, $\beta$-amyloid and $\alpha$-crystallin which, respectively, have an action on arteriosclerosis, Alzheimer's disease and cataracts. Sequence-dependent and sequence-independent are the two strategies for detecting the presence and position of D-amino acids in proteins. These methods rely on enzymatic digestion by a site-specific enzyme and acid hydrolysis in a deuterium or tritium environment to limit the natural racemization of amino acids. In this review, chromatographic and electrophoretic techniques, such as LC, SFC, GC and CE, will be recently developed (2018-2020) for the enantioseparation of amino acids and peptides. For future work, the discovery and development of new chiral stationary phases and derivatization reagents could increase the resolution of chiral separations.
\end{abstract}

Keywords: chiral separation; proteins; peptides; D-amino acids

\section{Introduction}

Homochirality is omnipresent in biological processes and is essential for the development and maintenance of life. The phenomenon is well known in saccharides when mono-, di-, oligo- and polysaccharides are found in their D-form. Fructose, galactose and glucose are natural monosaccharides found in fruits and vegetables. Lactose, maltose and sucrose are natural disaccharides are made up of galactose and glucose, two glucoses, and glucose and fructose, respectively. They are found in mammalian milk (lactose), malted grains (maltose) and plants, fruits and vegetables (sucrose). Each of them plays a role in human health and diseases. Indeed, these sugars are essential and provide the energy necessary for the proper organ function. Nevertheless, excess blood sugar can cause metabolic disorders such as diabetes [1,2]. Oligo- and polysaccharides are also found in vegetables, fruits and grains. These saccharides could offer a promising hypoglycemic potential, without side effects on the human body [3]. Oligo- and polysaccharides are naturally present as glycosylation on protein sequences. These post-translational modifications can play a physiological role in the human body. The change of nature of glycosylation on protein sequences can modulate inflammatory responses, allow viral immune escape, promotes the onset of cancer cell metastasis and regulate apoptosis [4]. Natural or synthesized drugs are other important source of chiral compounds necessary for life. Their $(R)$ - and $(S)$ enantiomers can be beneficial, neutral or toxic for human life, with different pharmacology and pharmacokinetics, which is why their enantioseparation is an important bioanalytical challenge. Several separation techniques can be used, including liquid chromatography, gas chromatography, supercritical fluid chromatography and capillary electrophoresis [5].

Not so commonly described as chiral, proteins and peptides are found mainly in their L-amino acid form. Properties of each amino acid in peptides and proteins can play a role in the global properties and function of the peptides and proteins they form. The L- and 
D-amino acids have very similar chemical and physical properties but differ in their optical character. Peptides containing L-amino acids would be in the $\alpha$-helical peptide by the left-handed helix rotation, and hypothetically all peptides containing D-amino acids could be in the $\alpha$-helical peptide by the right-handed helix rotation [6]. The spatial architecture of L-peptides and L-proteins allows them to play an important role in enzymatic specificity and structural interaction. D-peptides and D-proteins are also biostable to proteolytic enzymes [7]. When a D-amino acid appears in a L-peptide or L-protein sequence, the orientation of the amino acid side chain is reversed [8]. This inversion can change the peptide or protein properties, such as affinity for solvents and their interaction with other proteins [9]. However, the reasons for the elimination of D-amino acids in all living organisms composed mainly of L-amino acids are not well known [10]. Nevertheless, thanks to recent technological advances, some D-amino acids in peptides and proteins have been detected in various living organisms, including humans, and they have been found to be generated by enzymatic or non-enzymatic post-translational isomerization, especially in elderly patients, diseased tissues and those with innate immune defense [11-16]. Therefore, peptides and proteins containing D-amino acids which are linked to various diseases can be used as novel disease biomarkers, but the amount of research and papers is still limited. Among some peptides containing D-amino acids, the most famous examples are the agatoxins, dermorphin and gramicidin S. Agatoxins are a class of neurotoxin peptides isolated from the Agelenopsis aperta spider venom. Specifically, the $\omega$-agatoxin IV contains 48 amino acids on its sequence with a D-Ser residue at position 46 . Its main biological action is to block exclusively the P-type calcium channels. It has no activity against T-type, L-type or N-type calcium channels present on the neuron membranes [17]. Dermorphin is a heptapeptide found in the skin secretions of two frogs Phyllomedusa rhodei and Phyllomedusa sauvagei and contains a D-Ala at the second position. Thanks to this D-Ala, dermorphin has an affinity and selectivity for $\mu$-opioid receptors and has biological activity similar to morphine. However, this opioid activity is lost when the alanine is in its L-form [18]. Gramicidin $S$ is a cyclodecapeptide containing two D-Phe with antibiotic activity against some bacteria, produced by the Gram-positive bacterium Bacillus brevis, and is used to treat wound infections [19].

The list of peptides containing D-amino acid discovered to date is summarized in Table 1 , including the position of the D-amino acid. Proteinogenic D-amino acids may also be found in some proteins. Among the most famous examples, D-Asp has been found in the sequence of several proteins, such as elastin, myelin and $\beta$-amyloid; in the human aorta; and in the skin and brain tissue of patients with atherosclerosis and Alzheimer's diseases. Moreover, proteinogenic D-Asp, D-isoAsp, D-Asn, D-Glu, D-isoGlu, D-Ser and D-Thr have been found in the sequence of $\alpha$ - and $\beta$-crystallin contained in the human lens [12,20-23]. The isomerization of these amino acids under physiological conditions may change the higher-order structure of a protein, which in turn may have a role in age-related disorders such as cataracts [12]. Recently, Fujii et al. have proposed a relationship between protein aggregation and Asp isomerization, leading to the cataract formation [24].

Table 1. Position of D-amino acids in protein/peptide sequences.

\begin{tabular}{|c|c|c|c|c|}
\hline D-amino Acids & Proteins/Peptides & $\begin{array}{l}\text { Length of Amino } \\
\text { Acid Sequence }\end{array}$ & $\begin{array}{l}\text { Position on } \\
\text { the Sequence }\end{array}$ & Ref. \\
\hline D-Asp & Phosphophoryn & 1129 & undetermined & [25] \\
\hline D-Asp & Elastin & 786 & undetermined & {$[26,27]$} \\
\hline D-Ala & Ovalbumin & 385 & undetermined & {$[28]$} \\
\hline D-Asp & Ovalbumin & 385 & undetermined & [28] \\
\hline D-Glu & Ovalbumin & 385 & undetermined & [28] \\
\hline D-Pro & Ovalbumin & 385 & undetermined & {$[28]$} \\
\hline D-Ser & Ovalbumin & 385 & undetermined & [28] \\
\hline D-Asp & Myelin & 304 & 145 & [29] \\
\hline D-isoAsp & Myelin & 304 & 34,145 & [29] \\
\hline D-Asp, D-isoAsp & $\beta$ B1-crystallin & 252 & 211 & [23] \\
\hline
\end{tabular}


Table 1. Cont.

\begin{tabular}{|c|c|c|c|c|}
\hline D-amino Acids & Proteins/Peptides & $\begin{array}{l}\text { Length of Amino } \\
\text { Acid Sequence }\end{array}$ & $\begin{array}{l}\text { Position on } \\
\text { the Sequence }\end{array}$ & Ref. \\
\hline D-Asp & IgGK light chain & 214 & 151,170 & [15] \\
\hline D-Asp & $\beta$ B2-crystallin & 205 & 4 & [12] \\
\hline D-Asp & $\alpha \mathrm{B}$-crystallin & 175 & $36,62,140,143$ & {$[11,30]$} \\
\hline D-Ser & $\alpha \mathrm{B}$-crystallin & 175 & 59,66 & [23] \\
\hline D-Asn & $\alpha \mathrm{B}$-crystallin & 173 & undetermined & [21] \\
\hline D-Asp & $\alpha \mathrm{B}$-crystallin & 173 & $58,84,151$ & {$[20,23]$} \\
\hline D-Glu, D-isoGlu & $\alpha \mathrm{B}$-crystallin & 173 & 83 & [23] \\
\hline D-isoAsp & $\alpha \mathrm{B}$-crystallin & 173 & 84 & [23] \\
\hline D-Ser & $\alpha \mathrm{B}$-crystallin & 173 & 59,62 & {$[22]$} \\
\hline D-Thr & $\alpha \mathrm{B}$-crystallin & 173 & undetermined & [21] \\
\hline D-Tyr & Achatin-like neuropeptide & 158 & 56,86 & [31] \\
\hline D-Asp & Histone $\mathrm{H} 2 \mathrm{~B}$ & 126 & 25 & [32] \\
\hline D-Asp & Osteocalcin & 100 & undetermined & [33] \\
\hline D-Phe & Phenylseptin & 67 & 50 & {$[34]$} \\
\hline$D-\operatorname{Trp}$ & $\omega$-agatoxin IV & 48 & 46 & [17] \\
\hline D-Asp & $\beta$-amyloid & 42 & $1,7,23$ & [35] \\
\hline D-Ser & $\beta$-amyloid & 42 & 8,26 & [36] \\
\hline D-Asp & IgG H5 & 27 & 24 & {$[37]$} \\
\hline D-Asp & IgG L2 & 24 & 12 & [37] \\
\hline D-allo-Ile & Brombinin $\mathrm{H} 4$ & 21 & 2 & [38] \\
\hline D-Phe & Gramicidin S & 10 & cyclopeptide & [39] \\
\hline D-Asp & $\begin{array}{c}\text { mAb heavy chain CDR2 } \\
\text { peptide (51-59) }\end{array}$ & 9 & 4 & {$[40]$} \\
\hline D-Phe & Hyperglycemic hormone & 8 & 3 & [41] \\
\hline D-Trp & Contryphan & 8 & 4 & [42] \\
\hline D-Ala & Dermorphin & 7 & 2 & [18] \\
\hline D-Ala & Deltorphine & 7 & 2 & [43] \\
\hline D-Met & Dermenkephalin & 7 & 2 & [44] \\
\hline D-Asp & $\begin{array}{l}\text { Type } 1 \text { collagen C-terminal } \\
\text { telopeptide (1209-1214) }\end{array}$ & 6 & 3 & [45] \\
\hline D-Asn & Fulicin peptide & 5 & 2 & [46] \\
\hline D-Phe & Achatin I peptide & 4 & 2 & [47] \\
\hline
\end{tabular}

Amino acids can also be found in their free form in the human body and intervene in various diseases. Lee et al. are recently reported to free D-Ala has been found in the brain (white and gray matter, serum and cerebrospinal fluid) for patients with Alzheimer's disease, in the plasma and serum for renal disease, in the serum for liver cirrhosis and hepatocellular carcinoma, in the urine for short bowel syndrome and in the nails for diabetes [48]. Free D-Asp and D-Trp are also found in chickens and mammals including humans and rats. The list of free D-amino acids discovered is summarized in Table 2 by Ayon et al., as well as D-amino acid-containing peptides and proteins, their location and associated roles [49].

Table 2. List of various D-amino acids in higher organisms, their location and associated roles. Reproduced with permission from the authors of [49].

\begin{tabular}{ccccc}
\hline D-Amino Acids & Proteins/Peptides/Free AA & Source & Associated Disease/Function & Ref. \\
\hline D-Asp & Elastin & Aorta and skin $(\mathrm{H})$ & Arteriosclerosis & {$[26,27]$} \\
\hline Myelin & Brain $(\mathrm{H})$ & Alzheimer's disease & {$[50]$} \\
\hline B-amyloid & Brain $(\mathrm{H})$ & $\begin{array}{c}\text { Neuromodulatory effect } \\
\text { adrenal and pineal } \\
\text { glands }(\mathrm{R})\end{array}$ & $\begin{array}{c}\text { Inhibit secretion of melatonin } \\
\text { Increase testosterone production }\end{array}$ \\
\hline Free AA & [52-54] & \\
\hline
\end{tabular}


Table 2. Cont.

\begin{tabular}{|c|c|c|c|c|}
\hline D-Amino Acids & Proteins/Peptides/Free AA & Source & Associated Disease/Function & Ref. \\
\hline $\begin{array}{l}\text { D-Asp, D-Asn, } \\
\text { D-Ser and D-Thr }\end{array}$ & $\alpha$-crystallin & Lens $(\mathrm{H})$ & Cataract & [21] \\
\hline D-Ala & Dermorphin Deltorphine & Skin $(F)$ & $\begin{array}{l}1000 \text { times more analgesia than } \\
\text { morphine due to presence } \\
\text { of D-Ala }\end{array}$ & {$[18,43]$} \\
\hline D-Met & Dermenkephalin & Skin $(F)$ & Analgesia & [44] \\
\hline \multirow[t]{3}{*}{ D-Phe } & Achatin I & Ganglia and atrium (S) & $\begin{array}{c}\text { Enhances cardiac activity } \\
\text { Excitatory action on muscles }\end{array}$ & [47] \\
\hline & Hyperglycemic hormone & Sinus gland (L) & $\begin{array}{l}\text { Increase glucose concentration in } \\
\text { response to stress }\end{array}$ & {$[41,55]$} \\
\hline & Phenylseptin & Skin $(F)$ & Antimicrobial activity & [34] \\
\hline D-allo-Ile & Brombinin $\mathrm{H} 4$ & Skin $(F)$ & $\begin{array}{l}\text { Antimicrobial and } \\
\text { antiparasitic activity }\end{array}$ & [38] \\
\hline D-Asn & Fulicin peptide & Ganglia (S) & $\begin{array}{l}\text { Enhance concentration of penis } \\
\text { retractor muscle }\end{array}$ & [46] \\
\hline \multirow[t]{3}{*}{ D-Trp } & Contryphan & Venom (CS) & Paralysis of fish prey by snails & [42] \\
\hline & $\omega$-agatoxin & Venom (SP) & Calcium channel blocker & [17] \\
\hline & Free AA & Brain (M) & $\begin{array}{l}\text { N-methyl D-aspartate } \\
\text { (NMDA)/glycine } \\
\text { receptor agonist }\end{array}$ & [52] \\
\hline
\end{tabular}

Notes: H: Human; R: Rat; C: Chicken; F: Frog; S: Snail; L: Lobster; CS: Cone Snail; SP: Spider; M: Mammals.

Many of these examples come from aging proteins and prove that the homochirality of amino acids in proteins is not guaranteed throughout life and can cause disorders in the human body as age progresses. Therefore, it is important to determine the protein sequence, in particular the position of the supposed D-amino acids.

\section{Determination of Chiral Protein Sequences}

Due to sequence modification, determining the exact protein sequences can be difficult. These modifications are caused via an enzymatic or a non-enzymatic process. Among these modifications, most frequently of them are the isomerization of amino acids and some post-translational modifications. Amino acid enzymatic isomerization is possible via an amino acid racemase. These racemases are classed into two families: pyridoxal 5'-phosphate-dependent (alanine racemase AlaR, arginine racemase ArgR, aspartate racemase AspR, histidine racemase HisR, lysine racemase LysR and serine racemase SerR), and pyridoxal 5'-phosphate-independent (aspartate racemase AspR, glutamate racemase GluR and proline racemase ProR) $[16,56,57]$. These racemases can proceed to free amino acid isomerization before or during peptide elongation [58]. On the other hand, the natural conversion of L-amino acid residues to its D-enantiomers in peptides and proteins occurs by non-enzymatic isomerization via a succinimidyl intermediate under physiological conditions. Figure 1 shows the spontaneous isomerization of L-Asp and the deamidation of L-Asn to D-Asp residues via an intramolecular cyclization. This conversion mechanism can also be applied from L-Glu and L-Gln to D-Glu residues. Certain specific amino acid sites seem more favorable to this isomerization and their position and steric environment on the sequence can influence this isomerization [20]. Besides, this non-enzymatic isomerization is associated with aging or disease in general [59]. A kinetic factor can also influence isomerization during ageing. Indeed, Hooi et al. have shown the percentage of racemization, under physiological conditions, in healthy and disease patients as a function of their age. For this study, the racemization of L-Asx, L-Ser, L-Thr, L-Phe, L-Glx and L-Leu was assessed. For healthy lens samples from 12-year-old patients, the L-amino acid 
racemization rates were 5.7\%, 3.3\%, 2.7\%, 1.9\% and 1.6\%, respectively. For 80 -year-old patients, these rates were $12.6 \%, 5.9 \%, 3.5 \%, 2.3 \%, 2.0 \%$ and $1.6 \%$, respectively. Asx and Ser appear to be amino acids with faster isomerization throughout life. These two amino acids have also been studied in patients with cataracts. At 80 years of age, the racemization of L-Asx and L-Ser was $16.3 \%$ and $6.6 \%$, respectively. Compared with healthy patients, these levels are significantly higher and confirm the influence of the disease on the increase in the racemization of amino acids contained in the proteins of the human body [21].

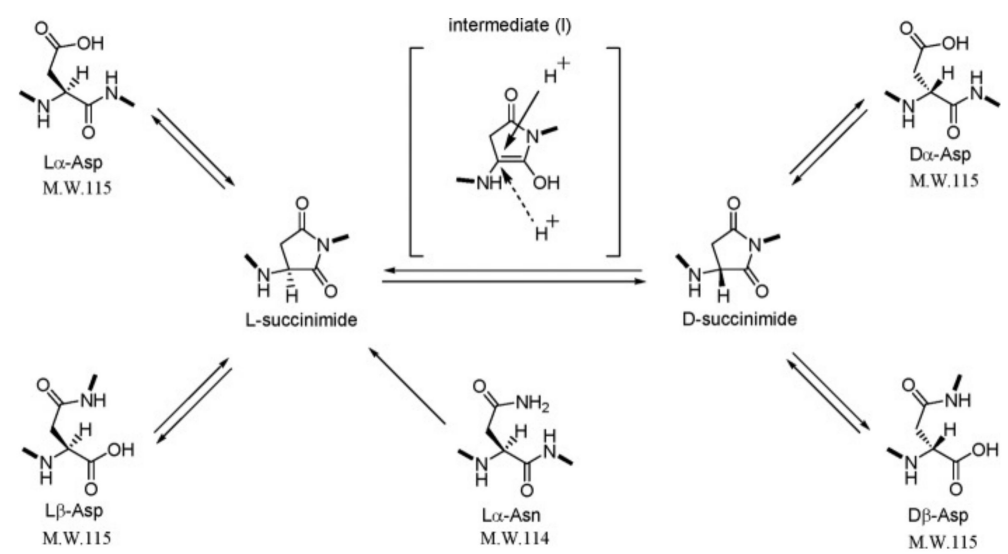

Figure 1. Possible reaction pathways for spontaneous isomerization of Asp and deamidation of Asn residues in protein. Reproduced with permission from the authors of [60].

However, in peptides and proteins, the conversion of L/D-amino is not uniform. Thus, it is necessary to examine each amino acid individually at each specific site susceptible to isomerization. Two strategies, as shown in Figure 2, can be used for the determination of chiral peptide and protein sequences: a sequence-dependent strategy and a sequenceindependent strategy [14].

(a) Sequence-dependent method

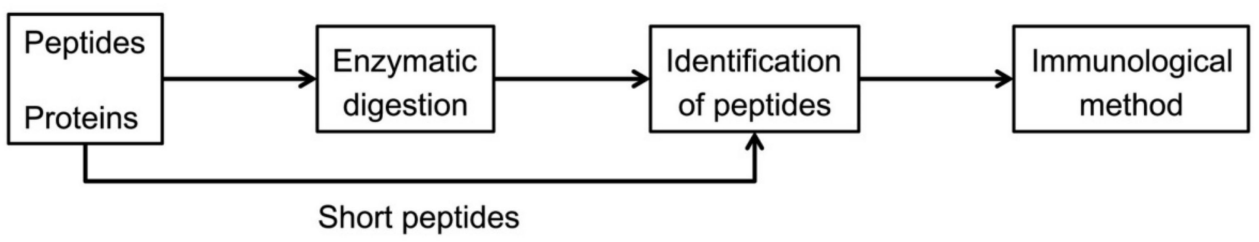

(b) Sequence-independent method

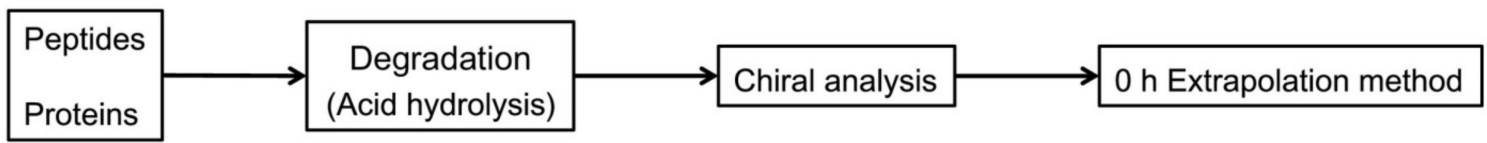

Figure 2. Flow charts for the determination of D-amino acid residues in peptides and proteins using (a) sequence-dependent and (b) sequence-independent analytical methods. Reproduced with permission from the authors of [14].

With the sequence-dependent strategy, i.e., peptide analysis, two methods can be applied to identify the isomerized position of the amino acid on the sequence. The first method consists of digesting the protein into several peptides by an enzyme. Each enzyme has its specific cleavage sites. Then, these peptides are separated by a chromatographic method, such as RP-HPLC, which is the most used. The collected peptide fractions are analyzed by mass spectrometry and their positions on the protein sequence are identified. 
These peptides are next hydrolyzed into amino acid residues and all react with a standard protected amino acid, such as Boc-L-cysteine [13] or Boc-L-Leucine [61]. This peptide coupling makes it possible to obtain LL- and DL-dipeptides with different retention times and to distinguishes the L- and D-amino acids of the same mass. Nevertheless, the temperature, $\mathrm{pH}$, metal ions and buffer can influence the efficiency of the peptide or protein enzymatic hydrolysis. Furthermore, recent studies have demonstrated the influence of chiral peptide sequence on enzymatic activity. Indeed, a D-amino acid on the specific cleavage site can prevent its recognition by the enzyme and block enzymatic activity. Moreover, the distance between a D-amino acid on the sequence and the specific site can also influence the degree of enzymatic cleavage [62]. The second method consists of homogenizing the protein in a natural buffer solution. After centrifugation, the water-soluble and water-insoluble fractions are collected. Both fractions are digested by an enzyme. Liquid chromatography coupled to mass spectrometry analysis is used for the separation of these digested peptides and their identification by sequencing coverage. Peptides containing different amino acid enantiomers have different retention times. Then, the retention time of each peptide is compared to that of standard synthesized peptides which several possibilities of enantiomer positions. With this approach, various enzymes or a combination of enzymes with different amino acid enantiomers at specific cleavage sites can be used. As an example, trypsin in association with endoproteinase Asp-N (cleavage at N-terminus L-Asp) [63], L-isoaspartyl methyltransferase (PIMT) (methylation of L-isoAsp) [14,32,35,37,63] and Daspartyl endoproteinase (DEAP) also named paenidase (cleavage at C-terminus D-Asp) [64] can recognize only $\mathrm{L}-\alpha$-Asp, $\mathrm{L}-\beta$-Asp and $\mathrm{D}-\alpha$-Asp residues respectively. Other proteases can be used to cleave proteins at specific sites, such as glutamyl endoproteinase Glu-C (cleavage at C-terminus L-Glu) for histone H2B [32] and human immunoglobulin G kappa chain [15] analyses.

The sequence-independent strategy, i.e., analysis of the content of whole amino acids in peptides and proteins consists of hydrolyze peptides and proteins, under acidic conditions and at high temperatures. D- and L-amino acids obtained were analyzed by enantioseparation. $\mathrm{HCl} / \mathrm{H}_{2} \mathrm{O}$ conditions were more frequently used for the hydrolysis of biological material. However, in a hydrogenated environment, the natural conversion of L-amino acids to its enantiomer can take place. Kaiser et al. have shown the rate of racemization of free and proteinogenic amino acids by two different hydrolysis processes [65]. In vapor phase hydrolysis, the average rate of racemization over 11 amino acids for free amino acids was $3.44 \%$, for amino acids of Bovine Serum Albumin (BSA) was 5.77\%, and for amino acids of Lysozyme was $3.87 \%$. The same liquid phase hydrolysis experiment showed that the average rate of racemization over 11 amino acids for free amino acids was $1.28 \%$, for amino acids of BSA was $2.06 \%$, and for amino acids of Lysozyme was $2.15 \%$. To limit this natural conversion due to the presence of hydrogen, a $\mathrm{DCl} / \mathrm{D}_{2} \mathrm{O}$ hydrolysis is frequently used [14,28,31,66]. Manning et al. also used a tritiated hydrochloric acid to correct for racemization during acid hydrolysis [67]. In a deuterated or tritiated environment, the hydrogen on the alpha carbon was exchanged with a deuterium or tritium atom and decreases considerably the racemization (Figure 3).

By combining these two previous strategies, another approach for determining the sequences of chiral proteins is possible. Indeed, Livnat et al. have reported the presence of two D-Tyr on GYFD and SYADSKDEESNAALSDFA peptides on achatin-like neuropeptide sequence from Aplysia californica. This approach takes place over three steps. First, neuropeptide was digested by an aminopeptidase $\mathrm{M}$ and resistant peptides were screening. Second, a $\mathrm{DCl} / \mathrm{D}_{2} \mathrm{O}$ hydrolysis was used to hydrolyze each resistant peptide. Hydrolyzed amino acids were derivatized with Marfey's reagent and their chirality was determined by liquid chromatography coupled to mass spectrometry. Finally, when the presence of a D-amino acid was confirmed, the retention time of the endogenous peptide was compared to standard synthetic peptides. A schematic is shown in Figures 4 and 5 [31]. 


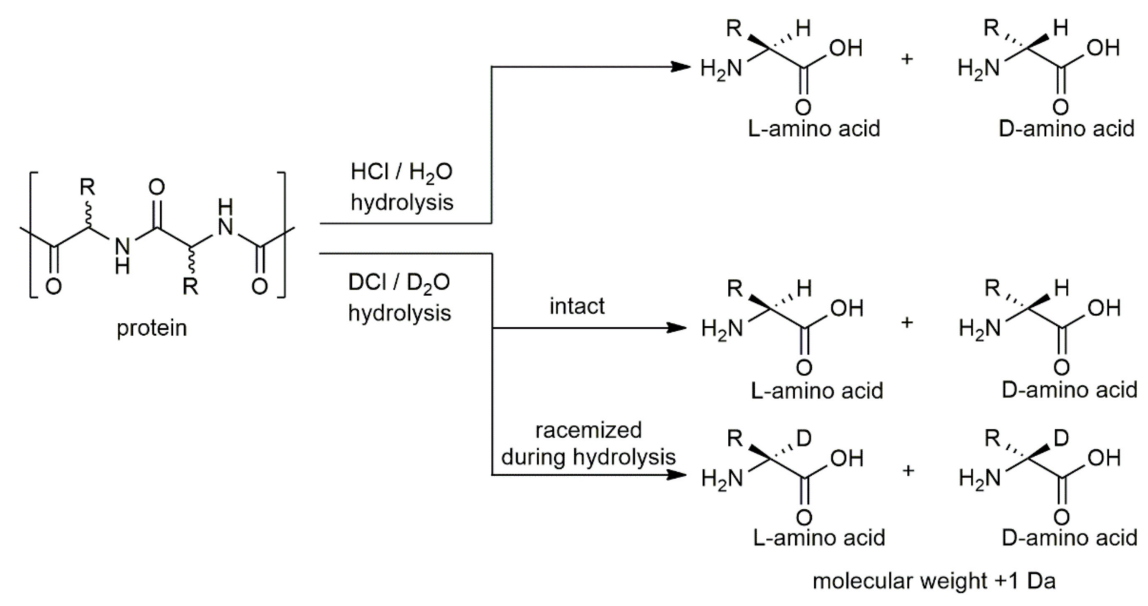

Figure 3. Amino acid racemization during protein hydrolysis under $\mathrm{HCl} / \mathrm{H}_{2} \mathrm{O}$ and $\mathrm{DCl} / \mathrm{D}_{2} \mathrm{O}$ conditions.

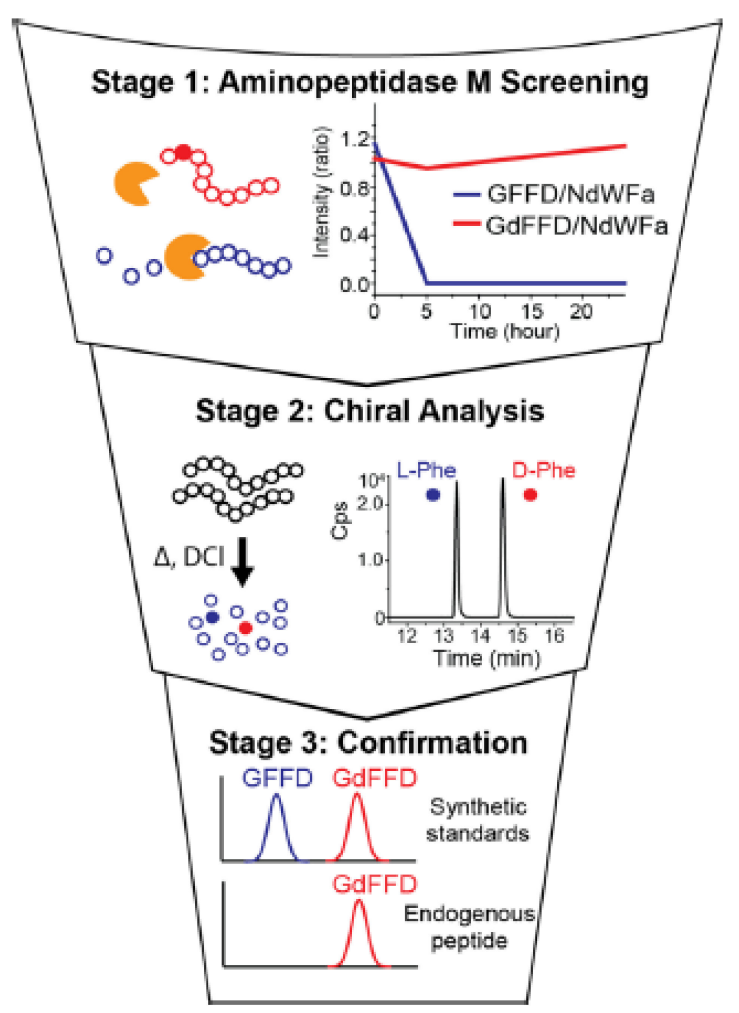

Figure 4. DAACP discovery funnel is capable of identifying DAACPs in three stages, as illustrated with GdFFD. In stage 1, MS-based detection of APM digestion is capable of identifying potential DAACPs in the screening phase of the discovery funnel. Here, GFFD, used as an example, is rapidly degraded after $5 \mathrm{~h}$, whereas its DAACP counterpart, GdFFD, is not degraded after $24 \mathrm{~h}$. Both are shown as a ratio to NdWF amide, a peptide that is known to resist degradation by APM. In stage 2, chiral analysis utilizes the MRM mode of MS to detect L- and D-amino acids in a peptide following acid hydrolysis and labeling. First, microwave-assisted vapor phase hydrolysis is carried out in DCl to break down peptides into their component amino acids. Importantly, DCl-based acid hydrolysis reduces detection of racemized residues in peptides. The amino acids are then labeled with Marfey's reagent, separated and detected using a triple quadrupole mass spectrometer. The result of this step is outlined using GdFFD, where a D-Phe is detected. In stage 3, confirmation of DAACPs, peptides are synthesized with the suspected chirality at each position and then compared to the endogenous peptides. Here, the retention time of the endogenous peptide matches that of the GdFFD synthetic standard, confirming its presence as a DAACP. Reproduced with permission from the authors of [31]. 

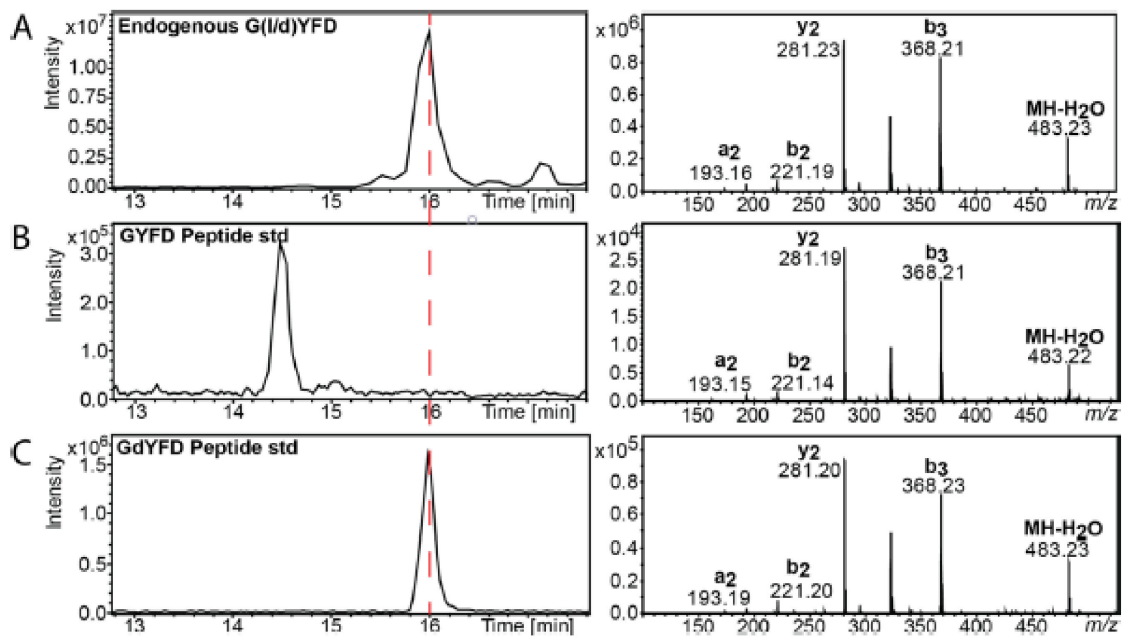

Figure 5. LC-MS/MS characterization of GdYFD, which is confirmed by comparing to the retention time of standards. (A) Left, LC-MS (base peak chromatogram) trace of endogenous GYFD after $48 \mathrm{~h}$ of APM digestion, with a retention time of $15.9 \mathrm{~min}$. Right, the MS/MS fragmentation with fragment assignments is shown. (B) Left, an LC-MS trace of the all-L-amino acid synthetic GYFD, with a retention time of $14.5 \mathrm{~min}$. Right, the MS/MS fragmentation with fragment assignments. (C) Left, an LC-MS trace of the synthetic DAACP GdYFD, with a retention time of $15.9 \mathrm{~min}$. Right, MS/MS fragmentation with fragment assignments is shown. The matching retention time of the synthetic GdYFD standard with the endogenous GYFD demonstrates that the sequence for the endogenous peptide is in fact GdYFD. Reproduced with permission from [31].

\section{Analysis of Chiral Amino Acids}

The presence of D-amino acids is confirmed in several peptides and proteins with important biological functions. Improvements in chiral analytical methods now allow precise detection and quantification of these D-amino acids in complex biological materials. Chromatographic and electrophoretic techniques coupled to mass spectrometry are the most popular platforms, owing to advances in chiral stationary phase (CSP) and derivatization chemistry. Employing a derivatization reagent contributes to the accurate detection of trace levels of proteinogenic amino acid enantiomers in different matrices. The separation of chiral amino acids or even peptides is only possible by a chiral approach which can be created by two methods: the direct or indirect method, described below.

\subsection{Direct Method}

The direct method consists of separating the optical isomers using a chiral selector by one of two following techniques. First, chiral selectors can be attached due to a chemical spacer into the surface of the stationary phase or the capillary. This chiral selector has a different affinity with both enantiomers. This selectivity follows the three points Dalgliesh rule: three interaction points between the chiral selector and enantiomer [68], where all functional groups of the chiral selector, asymmetric centres and steric repulsion are involved. Second, chiral selectors can be added to the mobile phase or the background electrolyte, defined as chiral mobile phase additives (CMPA) [69]. In the case of ionic enantiomers, a chiral compound can add to the formation of pairs of ions with enantiomers. Otherwise, a stereospecific compound can add to interact with only one of the enantiomers. Many groups of chiral compounds can be utilized as chiral selectors for the enantioseparation of amino acids or peptides. The main of them are polysaccharides [70] and cyclodextrins. However, in this review, we will also evaluate other chiral compounds as chiral selectors for the enantioseparation by liquid chromatography, supercritical fluid chromatography, gas chromatography and capillary electrophoresis.

The morphology of the chiral compounds used as a chiral selector can form three types of chiral stationary phase: fully-porous particles (FPP), superficially-porous particles 
(SPP) and non-porous particles (NPP) [71]. For the amino acid enantioseparation, the SPP columns appear to allow faster and more efficient separation than the FPP columns. Some examples will be described in the following section.

\subsubsection{Liquid Chromatography}

Enantioseparation by liquid chromatography needs a chiral environment. Several builder companies have developed commercial chiral columns. Zhao et al. have reported these columns with their target characteristics according to the type of chiral stationary phases and detailed are included in Table 3 [72].

Table 3. Target characteristics and commercial columns corresponding to chiral stationary phases (CSPs). Reproduced with permission from the authors of [72].

\begin{tabular}{|c|c|c|c|}
\hline Types of CSPs & Basic Material & Target Characteristics & Commercial Column \\
\hline Polysaccharides & Amylose or cellulose & $\begin{array}{l}\text { Widely applicable, such as } \\
\text { compounds containing amide } \\
\text { groups, aromatic ring } \\
\text { substituents, carbonyl nitro, } \\
\text { sulfonyl, cyano, hydroxyl, } \\
\text { amino and other groups, and } \\
\text { amino derivatives }\end{array}$ & $\begin{array}{c}\text { Chiralce }{ }^{\circledR} \mathrm{OD}, \text { Chiralpak }{ }^{\circledR} \mathrm{IB}, \\
\text { Lux }{ }^{\circledR} \text { Amylose-1, } \\
\text { Lux }{ }^{\circledR} \text { i-Amylose-1 }\end{array}$ \\
\hline Cyclodextrins & $\beta$-cyclodextin & $\begin{array}{l}\text { Widely applicable, such as } \\
\text { hydrocarbon compounds, } \\
\text { sterols, phenol esters and their } \\
\text { derivatives, aromatic } \\
\text { amines, polyheterocycles }\end{array}$ & $\begin{array}{c}\text { B-DEXTM225, Astec } \\
\text { Cyclobond }{ }^{\circledR}, \text { I } 2000 \text { RSP, } \\
\text { LiChroCART }^{\circledR} 250-4, \\
\text { ChiraDex }^{\circledR}\end{array}$ \\
\hline Proteins & $\begin{array}{l}\text { Enzymes, plasma proteins, } \\
\text { receptor proteins }\end{array}$ & Water-soluble medicine & $\begin{array}{l}\text { Chiralpak }{ }^{\circledR} \mathrm{HAS}, \\
\text { Resolvosil }{ }^{\circledR} \mathrm{BSA}, \\
\text { Chiralpak }^{\circledR} \text { AGT }\end{array}$ \\
\hline Crown ethers & Macrocyclic polyester & $\begin{array}{l}\text { Amino acids, amino alcohools, } \\
\text { primary amines }\end{array}$ & $\begin{array}{l}\text { Crownpak }{ }^{\circledR} \mathrm{CR}(+) / \mathrm{CR}(-), \\
\text { Chirosil }{ }^{\circledR} \mathrm{RCA}(+) / \operatorname{RAC}(-)\end{array}$ \\
\hline Pirkle type & $\begin{array}{l}\text { Amine, amino alcohol, amino } \\
\text { acid derivative compounds, } \\
\text { anthrone derivatives }\end{array}$ & $\begin{array}{c}\text { Widely applicable, CSPs } \\
\text { designed by analyzing } \\
\text { the target }\end{array}$ & Whelk-O1 ${ }^{\circledR}, \mathrm{ULMO}^{\circledR}{ }^{\circledR}$, Chirex $^{\circledR}$ \\
\hline Ion exchange type & $\begin{array}{l}\text { Cinchona alkaloids, } \\
\text { sulfamic acid }\end{array}$ & $\begin{array}{l}\text { N-protected amino acid, } \\
\text { N-protected amino group, } \\
\text { sulfamic acid, amino } \\
\text { phosphoric acid, aromatic } \\
\text { carbonyl acid }\end{array}$ & $\begin{array}{c}\text { Chiralpak }{ }^{\circledR} \mathrm{QN}-\mathrm{AX}, \\
\text { Chiralpak }{ }^{\circledR} \mathrm{QD}-\mathrm{AX}, \\
\text { Chiralpak }^{\circledR} \mathrm{ZWIX}(+), \\
\text { Chiralpak }^{\circledR} \text { ZWIX (-) }\end{array}$ \\
\hline Macrocyclic glygopeptides & $\begin{array}{c}\text { Avomycin, Ristomycin A, } \\
\text { Vancomycin, Teicoplanon and } \\
\text { Teicoplanon aglycone }\end{array}$ & $\begin{array}{l}\text { Widely applicable, such as } \\
\text { amino acids, peptides, } \\
\text { non-steroidal } \\
\text { anti-inflammatory drugs }\end{array}$ & $\begin{array}{c}\text { Astec }{ }^{\circledR} \mathrm{CHIROBIOTIC}^{\circledR} \mathrm{V}, \\
\text { Astec }^{\circledR} \mathrm{CHIROBIOTIC}{ }^{\circledR} \mathrm{R}, \\
\text { Astec }^{\circledR} \mathrm{CHIROBIOTIC}{ }^{\circledR} \mathrm{TAG}\end{array}$ \\
\hline Cyclofructans & Cyclic oligosaccharides & $\begin{array}{l}\text { Primary amine, acid, } \\
\text { secondary amine, tertiary } \\
\text { amine, alcohol }\end{array}$ & Larihc ${ }^{\circledR}$ CF6-RN \\
\hline Porous organic materials & $\begin{array}{c}\text { Covalent organic framework, } \\
\text { metal organic framework, } \\
\text { metal organic cage, } \\
\text { mesoporous silica }\end{array}$ & $\begin{array}{l}\text { Halogenated hydrocarbons, } \\
\text { ketones, esters, ethers, organic } \\
\text { acids, alkylene oxides, } \\
\text { alcohols and sulfoxides }\end{array}$ & / \\
\hline
\end{tabular}

Here, we will describe different chiral stationary phases, such as polysaccharides, cyclodextrins, crown ethers, Pirkle type, ion-exchange type and macrocyclic glycopeptides, for the chiral separation of amino acids and peptides. 


\section{Polysaccharide-Based Chiral Stationary Phases}

Chiral stationary phases based on polysaccharides are probably the most used owing to the many different columns for enantioseparations by liquid chromatography. Commercial cellulose- and amylose-based columns are most popular, however synthesized columns based on chitosan, xylan, curdlan, dextran and inulin may also be found [73]. Indeed, Lin et al. have evaluated 17 amylose and cellulose-based columns, both coated and immobilized, for chiral pharmaceutical analysis [74]. Different types of cellulose and amylose-based chiral selectors and their derivatives, the effect of substituents and carrier on properties of polysaccharide-based CSPs, and optimizations of the CSP and the mobile phase for separation of enantiomers by high-performance liquid chromatography (HPLC) have been summarized by Chankvetadze [75].

\section{Cyclodextrin-Based Chiral Stationary Phases}

Cyclodextrins are frequently used for the separations of chiral compounds, as chiral stationary phases as well as novel polysaccharides. Many article reviews and book chapters generally describe $\alpha-, \beta-, \gamma$ - and modified-cyclodextrins for the separation of enantiomeric compounds by liquid chromatography [76,77]. More recently, Li et al. have described the synthesis of a triazole-bridged duplex CD-CSP and its application for the enatioseparation of Dns-Leu and Dns-Phe by HPLC [78]. Shuang et al. synthesized a new chiral stationary phase based on $\beta$-cyclodextrin for the enantioseparation of five derivatized and three underivatized DL-amino acid enantiomers by high-performance liquid chromatography. The results obtained with the new ethylenediamine dicarboxyethyl diacetamido-bridged bis $(\beta-\mathrm{CD})$-bonded chiral stationary phase (EBCDP) were compared with those obtained with the native $\beta$-CD chiral stationary phase (CDSP). For each Dns-DL-amino acid enantiomer, the EBCDP has offered a better separation than the CDSP. The same trend was observed for the enantioseparation of underivatized DL-amino acids, with the addition of copper ion $\mathrm{Cu}$ (II) into the mobile phase, exhibiting a property of the chiral ligand exchange chromatography [79].

\section{Crown Ether-Based Chiral Stationary Phases}

Among the various crown ether-based columns, Crownpak CR-I (+) has been used in all recent studies. With this column, the retention time of D-amino acid was shorter than their L-amino acid enantiomers with a primary amino group [80,81]. For the separation of proteinogenic and non-proteinogenic amino acid enantiomers with the same molecular mass, Nakano et al. [82] have separated L-Ile, L-allo-Ile, L- and D-Leu while D-Ile and D-allo-Ile were co-eluted with the Crownpak CR-I (+) column. Using the Crownpak CRI (-) column, D-Ile, D-allo-Ile and L-Leu were separated while L-Ile and L-allo-Ile were co-eluted (Figure 6) [82]. Meanwhile, Yoshikawa et al. have separated DL-Ile, DL-allo-Ile and DL-Leu with the Crownpak CR-I (+) column. Similar results were obtained for the enantioseparation of DL-Thr, DL-allo-Thr and DL-Hse [80]. Nakano et al. have separated L-Thr, L-allo-Thr and L-Hse while D-Thr, D-allo-Thr and D-Hse were co-eluted with the Crownpak CR-I (+) column. Using the Crownpak CR-I (-) column, D-Thr, D-allo-Thr and D-Hse were separated while L-Thr, L-allo-Thr and L-Hse were co-eluted (Figure 6) [82]. Yoshikawa et al., have separated only DL-Thr with the Crownpak CR-I (+) column, DL-alloThr and DL-Hse were not studied [80]. The exchange of columns Crownpak CR-I (+) and CR-I ( -$)$ reversed the elution order for each compound. However, for the secondary amino group, such as DL-Pro, the Crownpak CR-I (+) column did not offer separation while the Chiralpak ZWIX (-) column did (Figure 6) [82]. 

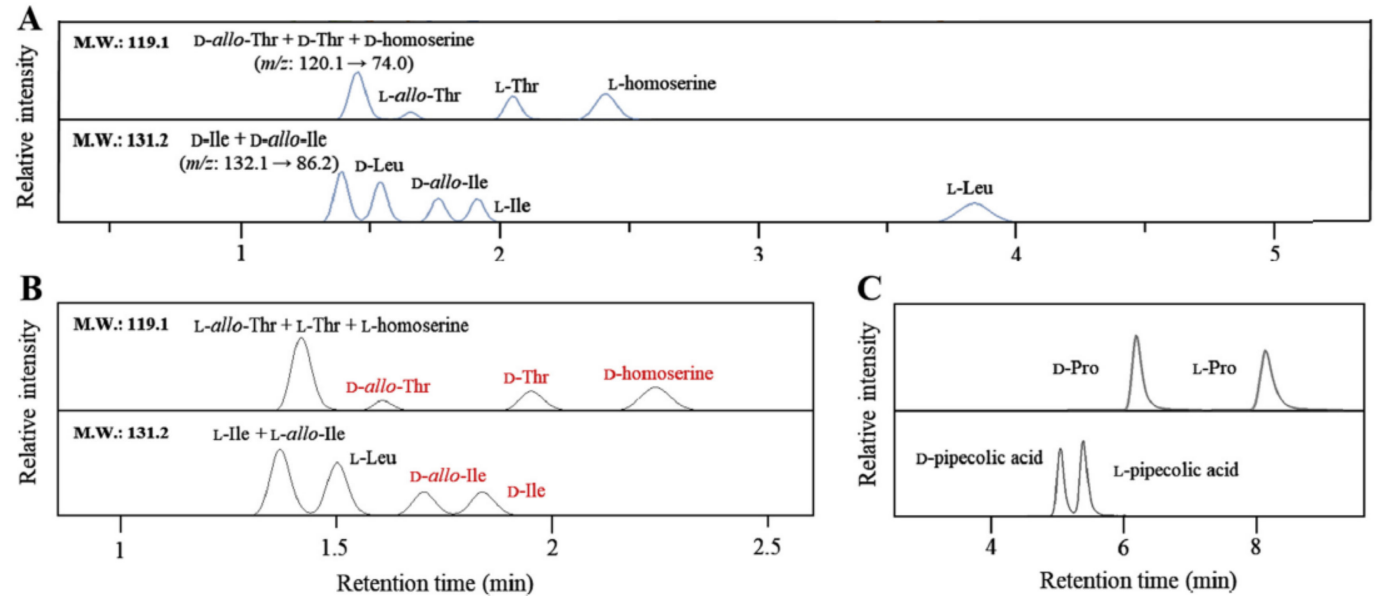

Figure 6. The chromatograms obtained by Crownpak CR-I (+), CR-I (-) and Chiralpak ZWIX (-). (A) Partial chromatograms of targeted compounds with the same molecular weight obtained by LC-MS/MS analysis using Crownpak CR-I (+). These chromatograms were obtained from a $1 \mathrm{nmol} / \mathrm{mL}$ mix standard solution (Thr, threonine; Ile, isoleucine; and Leu, leucine). The same color peaks were detected in the same MRM transition. Most compounds showed baseline separation while some compounds including D-allo-Thr, D-Thr, and D-homoserine or D-Ile and D-allo-Ile co-eluted. (B) Extracted ion chromatograms using Crownpak CR-I (-). The chromatogram for the MRM transition of m/z 120.1 to 74.0 (molecular weight: 119.1) and 132.1 to 86.2 (molecular weight: 131.2). The CR-I (-) column reversed the elution order for each compound from the CR-I (+) column. (C) A part of chromatogram of secondary amines by using Chiralpak ZWIX (-). The ZWIX column, with zwitterionic molecules that incorporated both anion and cation-exchange functional groups, enabled the separation of secondary amines including proline (Pro). Adapted from the work in [82] with permission.

Concerning the enantioseparation of biological and synthesized peptides, the retention times of LXX or LXXX peptides were shorter than DXX or DXXX peptides using the Crownpak CR-I (+) column, whereas the migration order was reversed using the Crownpak CR-I (-) and ChiroSil RCA (+) columns. The chirality of the first amino acid seems to influence the retention time and different interactions and affinity with the column than its enantiomer $[34,81]$. In addition, the chirality of the second amino acid contained in the peptide sequence also influences the retention time. Indeed, peptides with a L-Phe (XLX) at the second position was more retained than peptide with a D-Phe (XDX). By using this column, the position of D-Phe in the tripeptide $(\mathrm{Phe})_{3}$ from the amphibian antimicrobial DL-phenylseptin (Table 4) was elucidated [34]. The order of migration also changed according to the percentage of acetonitrile contained in the mobile phase [81]. In those cases, the Crownpak CR-I $(+)$ column offered a better separation for a complex mixture of different peptide enantiomers.

Table 4. Comparison of peptide separation performances using the ChiroSil RCA (+), Crownpak (+) and Chrownpak (-) columns.

\begin{tabular}{|c|c|c|c|c|c|c|c|}
\hline \multirow{3}{*}{$\begin{array}{l}\text { Samples } \\
\text { Peptides }\end{array}$} & \multicolumn{6}{|c|}{ Column } & \multirow{3}{*}{ Ref. } \\
\hline & \multicolumn{2}{|c|}{ ChiroSil RCA (+) } & \multicolumn{2}{|c|}{ Crownpak (+) } & \multicolumn{2}{|c|}{ Crownpak (-) } & \\
\hline & Rs & $\alpha$ & Rs & $\alpha$ & Rs & $\alpha$ & \\
\hline LLL/DDD-(Phe) 3 & - & - & - & 5.58 & - & 1.28 & \\
\hline LDL / DLD-(Phe) $)_{3}$ & - & - & - & - & - & - & [34] \\
\hline LLD / DDL-(Phe $)_{3}$ & - & - & - & - & - & - & [34] \\
\hline LDD / DLL-(Phe) 3 & - & - & - & - & - & - & \\
\hline DLDL / LDLD-Tyr-Arg-Phe-Lys- $\mathrm{NH}_{2}$ & 3.08 & 1.51 & 4.68 & 1.48 & & & \\
\hline DDLL / LLDD-Tyr-Arg-Phe-Lys- $\mathrm{NH}_{2}$ & 4.76 & 1.92 & 9.46 & 2.39 & & & \\
\hline DLLL/LDDD-Tyr-Arg-Phe-Lys- $\mathrm{NH}_{2}$ & 3.51 & 1.61 & 10.62 & 2.56 & & & {$[81]$} \\
\hline DLDD/LDLL-Tyr-Arg-Phe-Lys- $\mathrm{NH}_{2}$ & 3.00 & 1.52 & $<0.50$ & 1.04 & & & \\
\hline DDLD/LLDL-Tyr-Arg-Phe-Lys- $\mathrm{NH}_{2}$ & 3.14 & 1.51 & 5.75 & 1.65 & & & \\
\hline
\end{tabular}


Finally, for the enantioseparation of proteinogenic amino acids, the Crownpak CR-I (+) column with $3 \mu \mathrm{m}$ particle size offered a better resolution than the same column with $5 \mu \mathrm{m}$ particle size, especially for amino acids strongly retained. Indeed, for compounds that are poorly retained, such as DL-His, their resolutions were 1.2 and 1.5 with $5 \mu \mathrm{m}$ and $3 \mu \mathrm{m}$ particle size columns, respectively, and for DL-Lys which, was strongly retained, their resolutions were 4.1 and 6.1 with the $5 \mu \mathrm{m}$ and $3 \mu \mathrm{m}$ particle size columns, respectively. Moreover, the separation time was reduced when the length of the column was shorter [80].

\section{Brush-Type or Pirkle-Type Chiral Stationary Phases}

Neutral synthetic chiral low-molecular-mass molecules are typically covalently linked to a silica support, which can have monosubstituted or trisubstituted silane groups through a spacer to create Pirkle-type chiral stationary phases $[83,84]$. The advantages of this type of column are the compatibility with a wide range of solvents used as mobile phase and stability against temperature and pressure [85]. Brush-type or Pirkle-type chiral stationary phases are classified into three groups: donors of $\pi$-electron/acceptor of $\pi$-electron (such as Whelk-O 1, Whelk-O 2, DACH-DNB and ULMO columns), acceptors of $\pi$-electron (such as Alpha burke 2, Leucine, Phenylglycine, Pirkle 1-J, $\beta$-Gem 10), and donors of $\pi$-electron (such as Naphtylleucine). Kohout et al. have studied the influence of the nature of Brushtypes CSP in combination with a 9-O-tert-butylcarbamoylquinidine as a chiral selector. In that work, three different FPP_Daiso silica (CSP 1, $5 \mu \mathrm{m}, 120 \AA$ ), Kromasil silica (CSP 2, $5 \mu \mathrm{m}, 100 \AA$ ) and YMC silica (CSP 3, $5 \mu \mathrm{m}, 120 \AA$ )—were used. The averages of resolutions obtained for the enantioseparation of eight different analytes were promising $(5.24,4.21$ and 4.79 for CSP 1, CSP 2 and CSP 3, respectively). The study showed the influence of the characteristics (nature, particle diameter and pore size) of the CSP used on the chromatographic performances [86]. Hsiao et al. have separated the DL-Phe enantiomers contained in physiological fluids of mammals, including humans, by 2D-HPLC. The D- and L-Phe was derivatized by 4-fluoro-7-nitro-2,1,3-benzoxadiazole (NBD-F) and separated by a reverse phase column for the first dimension and a Pirkle-type column with L-Leucine as a chiral selector for the second dimension. The same study showed the presence of $0.1 \%$ and $3.99 \%$ of D-Phe in the human plasma and urine, respectively. However, the authors planned further studies using this analytical method on various disease samples [87].

\section{Ion- and Zwitterion-Exchange-Based Chiral Stationary Phases}

Bäurer et al. have demonstrated the chiral chromatography characteristics of Chiralpak ZWIX (+) and ZWIX (-) columns based on zwitterionic quinine and quinidine carbamate selectors for the enantioseparation of proteinogenic amino acids by tandem liquid chromatography. For this work, molecular dynamics simulations, lipophilicity/hydrophilicity measurements of selectors, $\mathrm{pH}$-dependent $\zeta$-potential determinations and chromatographic characterization were studied for both columns [88]. Geibel et al. have demonstrated the Chiralpak ZWIX column with superficially-porous particles (SPP) allowed a better separation performance than a Chiralpak ZWIX column with fully-porous particles (FPP) [89].

Different anion- and zwitterion-exchange columns such as Chiralpak QN-AX, Chiralpak QD-AX, KSAAAX, Chiralpak ZWIX (+) and Chiralpak ZWIX (-) have been recently used for the enantioseparation of DL-amino acids and peptides, and were applied to biological samples in the discovery of new potential biomarkers for some diseases. Among these columns, Chiralpak QN-AX and Chiralpak ZWIX (+) have been used more, either alone or in tandem. With these two columns, free derivatized D-amino acids or D-amino acid-containing peptides at the first position were less retained on the column than their L-amino acid enantiomers. In contrast, with the Chiralpak QD-AX and Chiralpak ZWIX $(-)$ columns, the migration order was reversed.

Zhu et al. used the Chiralpak QN-AX column for the enantioseparation of 13 FmocDL-amino acids. The chromatographic performances (resolution and separation factor $\alpha$ ) were compared to those obtained thanks to new synthesized chiral selectors based on 3,5dimethylphenyl carbamoylated $\beta$-cyclodextrin connecting quinine (QN) or quinidine (QD) 
to create two chiral stationary phases ( $\beta$-CD-QN- and $\beta$-CD-QD-based CSP). The Chiralpak QN-AX column allowed separation of 11 out of 13 Fmoc-DL-amino acids with a resolution greater than 1.5, including seven Fmoc-DL-amino acids which had the best resolution (Asn, Thr, Ile, Leu, Met, Val and Phe) to compare to these two other experimental columns [90]. Bajtai et al. have applied this column to the enantioseparation of 20 dipeptide couples, but only seven of them obtained a good separation (LL/DD-Ala-Phg, LL/DD-Ala-Phe, LL/DDAla-Tyr, LL / DD-Ala-4-NO ${ }_{2}-\mathrm{Phe}$, LL / DD-Ala-Trp, LL/DD-Phe-Ala and LL/DD-Leu-Leu). Nevertheless, 10 dipeptide couples have not been separated (LL/DD-Ala-Ala, LD/DL-AlaAla, LL / DD-Ala- $\beta$-Phe, LL / DD-Ala-Phe, LL / DD-Ala-hPhe, $\beta$-Ala-L/ D-Phe, Gly-L/ D-Phe, LD/DL-Phe-Ala, LL/DD-Lys-Phe and LD/DL-Leu-Leu) [91] (Table 5).

Table 5. Comparison of peptides separation performances using the ion-exchange (QN-AX and QD-AX) and zwitterionic (ZWIX (+) and ZWIX (-)) columns.

\begin{tabular}{|c|c|c|c|c|c|c|c|c|c|}
\hline \multirow{4}{*}{$\begin{array}{l}\text { Samples } \\
\text { Peptides }\end{array}$} & \multicolumn{8}{|c|}{ Column } & \multirow{4}{*}{ Ref. } \\
\hline & \multicolumn{4}{|c|}{ Ion-Exchange } & \multicolumn{4}{|c|}{ Zwitterionic } & \\
\hline & \multicolumn{2}{|c|}{ QN-AX } & \multicolumn{2}{|c|}{ QD-AX } & \multicolumn{2}{|c|}{ ZWIX (+) } & \multicolumn{2}{|c|}{ ZWIX (-) } & \\
\hline & Rs & $\alpha$ & Rs & $\alpha$ & Rs & $\alpha$ & Rs & $\alpha$ & \\
\hline LL-Ala-Ala & 0 & 1.00 & 1.07 & 1.75 & 0.29 & 1.03 & 1.24 & 1.35 & \multirow{20}{*}{ [91] } \\
\hline LD-Ala-Ala & 0 & 1.00 & 0 & 1.00 & 0.97 & 1.14 & 0.21 & 1.03 & \\
\hline LL-Ala-Phg & 2.35 & 1.46 & 2.44 & 1.52 & 0.94 & 1.13 & 1.15 & 1.17 & \\
\hline LL-Ala- $\beta$ Phe & 0 & 1.00 & 0 & 1.00 & 0.90 & 1.09 & 0 & 1.00 & \\
\hline LL-Ala-Phe & 1.82 & 1.25 & 2.43 & 1.40 & 1.03 & 1.13 & 0.80 & 1.12 & \\
\hline LD-Ala-Phe & 0 & 1.00 & 0 & 1.00 & 0.53 & 1.12 & 1.29 & 1.17 & \\
\hline LL-Ala-hPhe & 0 & 1.00 & 1.56 & 1.30 & 0 & 1.00 & 0.90 & 1.20 & \\
\hline$\beta$ Ala-L-Phe & 0 & 1.00 & 1.05 & 1.15 & 4.36 & 1.45 & 2.50 & 1.34 & \\
\hline LL-Ala-Phe-OMe & - & - & - & - & 0 & 1.00 & 0 & 1.00 & \\
\hline LL-Ala-Phe- $\mathrm{NH}_{2}$ & - & - & - & - & 0 & 1.00 & 0.55 & 1.12 & \\
\hline LL-Ala-Tyr & 2.36 & 1.34 & 2.47 & 1.48 & 1.52 & 1.21 & 1.30 & 1.42 & \\
\hline LL-Ala-4-NO ${ }_{2}-\mathrm{Phe}$ & 1.88 & 1.25 & 0.82 & 1.09 & 1.96 & 1.28 & 2.00 & 1.46 & \\
\hline LL-Ala-Trp & 2.36 & 1.51 & 2.35 & 1.58 & 7.09 & 2.21 & 3.50 & 1.96 & \\
\hline Gly-L-Phe & 0 & 1.00 & 1.89 & 1.49 & 0 & 1.00 & 0.53 & 1.19 & \\
\hline L-Phe-Gly & 0.63 & 1.14 & 1.52 & 1.28 & 3.21 & 1.33 & 2.00 & 1.26 & \\
\hline LL-Phe-Ala & 4.36 & 1.52 & 4.73 & 2.01 & 2.55 & 1.55 & 2.94 & 1.40 & \\
\hline LD-Phe-Ala & 0 & 1.00 & 0 & 1.00 & 2.71 & 1.44 & 0.97 & 1.17 & \\
\hline LL-Lys-Phe & 0 & 1.00 & 2.14 & 1.71 & 1.95 & 1.28 & 0.94 & 1.12 & \\
\hline LL-Leu-Leu & 3.20 & 2.19 & 4.00 & 2.37 & 1.40 & 1.15 & 0.63 & 1.17 & \\
\hline LD-Leu-Leu & 0 & 1.00 & 0 & 1.00 & 1.77 & 1.24 & 0.53 & 1.16 & \\
\hline
\end{tabular}

The Chiralpak ZWIX (+) column has been used by several groups for the enantioseparation of derivatized or underivatized common and uncommon DL-amino acids and dipeptide couples. Indeed, Horak et al. have compared the separation factor $\alpha$ for the enantioseparation of derivatized or underivatized common and uncommon DL-amino acids. This study has shown to the Chiralpak ZWIX (+) column offers a better separation to ACQ-DL-amino acids than underivatized amino acids, except for DL-Pro [92,93]. For this work, the authors do not study the DL-Cys. Nevertheless, Pucciarini et al. have developed a method for the separation of standard ACQ-DL-Cys, with a good resolution (Rs: 2.7). Then, the authors have applied this cysteine analysis method to human lung adenocarcinoma A549 cells (ATCC, CCL-185) samples, and the resolution obtained was similar to cysteine standards. The study allows showing the presence of D-Cys in biological samples [94]. These results are promising because it has been shown that D-Cys protects neurons against oxidative stress thanks to its hydrogen sulfide production properties and promotes dendritic development [95]. For the enantioseparation of underivatized dipeptides, Bajtai et al. have obtained a similar average separation factor $\alpha$ to the enantioseparation of underivatized amino acids in the study by Horak's group describe earlier. However, for some dipeptide, the authors have obtained good resolutions ( $\beta$-Ala-L/D-Phe, LL / DD-Ala-Tyr, 
LL / DD-Ala-4-NO ${ }_{2}$-Phe, LL / DD-Ala-Trp, L / D-Phe-Gly, LL / DD-Phe-Ala, LD / DL-Phe-Ala, LL/DD-Lys-Phe and LD/DL-Leu-Leu) [91] for details see Table 5.

Kimura et al. used these two Chiralpak QN-AX and Chiralpak ZWIX (+) columns by chiral tandem liquid chromatography. For this study, the authors found the same enantiomer migration order (EMO) with both columns to one of these columns alone, as in the previous works described above. For amino acids with a primary amine, ACQ-D-amino acids were a faster elution than their counterpart ACQ-L-amino acids, except for DL-Pro which is a secondary amine and which has a reverse EMO. The results of resolution and separation factor $\alpha$ of the simultaneous $24 \mathrm{~L}$-amino acids and trace D-amino acids, which includes all proteinogenic amino acids and non-proteinogenic amino acids such as citrulline (Cit) and ornithine (Orn), contained in the human blood were not described. In this study, the blood of 305 women aged 65 to 80 who passed a Mini-Mental State Examination (MMSE), and classified into three groups: control, Mind Cognitive Impairment (MCI) and dementia was analyzed. This high sensitivity analytical method can detect a slight difference in the number of chiral amino acids and be developed to examine cognitive decline based on the difference detected. Indeed, the blood analysis of patients in the MCI group showed a higher proportion of D-Pro than the control group. Furthermore, the combination of D-Pro $x$ D-Ser proportions improved the correlation with early cognitive decline described by MMSE. Finally, D-Pro and D-Ser were also found in the blood of the dementia group with a higher proportion than in the MCI group. These amino acids can also be used to monitor dementia. These results showed that the proportion of D-Pro in the blood was strongly associated with early cognitive decline and may represent a new index of brain health. This tandem method of analysis, in less to $40 \mathrm{~min}$, might apply to practical medical evaluations to monitor the early risk of cognitive decline with high precision [96].

The Chiralpak ZWIX (-) has also been used for the enantioseparation of derivatized or underivatized DL-amino acids and dipeptide couples. For underivatized DL-amino acids, separation factors $\alpha$ obtained were better using the Chiralpak ZWIX $(-)$ when compared to the Chiralpak ZWIX (+) column, except for Trp and Glu [92]. The same group also compared both columns for the enantioseparation of ACQ-DL-amino acids. Conversely, the Chiralpak ZWIX (+) column allowed to obtain better separation factors $\alpha$ than the Chiralpak ZWIX (-), except for Pro, aThr, His and Arg [93]. Bajtai et al. have also used Chiralpak ZWIX (+) to compare both zwitterionic columns for the enantioseparation of 20 dipeptide couples. The separation factors $\alpha$ and the resolutions have shown that the Chiralpak ZWIX (+) column offered a better separation [91] see Table 5 .

The Chiralpak QD-AX column has only been used by Bajtai et al. to compare the Chiralpak QN-AX column for enantioseparation of dipeptide couples [91]. The separation factors $\alpha$ and the resolutions have shown that the Chiralpak QD-AX column offered a better separation significantly (Table 5).

To compare these two zwitterion-exchange columns, the average separation factor $\alpha$ was better with the Chiralpak ZWIX (+) column for underivatized and ACQ-DL-amino acids (1.21 and 2.33, respectively) than with the Chiralpak ZWIX (-) column (1.29 and 2.03 respectively). In addition, the Chiralpak ZWIX (+) also offered a better dipeptide enantioseparation with an average resolution of 1.66 compared to 1.20 with the Chiralpak ZWIX (-) column. For these two anion-exchange columns, the Chiralpak QD-AX column offered a better separation of dipeptide enantiomers with a resolution average of 2.12 compared to 1.05 with the Chiralpak QN-AX column. Regarding the Fmoc-DL-amino acids enantioseparation, only the Chiralpak QD-AX column was used and offered an excellent resolution average of 2.94. Both Chiralpak ZWIX (+) and Chiralpak QD-AX columns are to be preferred for the derivatized and underivatized amino acids and small peptides enantioseparation.

Concerning the anion-exchange column KSAAAX, Furusho et al. have separated four NBD-DL-amino acids contained in the plasma of 25 patients with chronic kidney disease (CKD) using a 3D-HPLC system. Several studies agree on the potential correlation between kidney disease and the presence of D-amino acids [97]. The 3D-HPLC system equipped 
with one KSAAAX column in combination with a reversed-phase and enantioselective columns allows separation of all compounds according to their hydrophobicity, anionic strength and enantioselectivity, which increases the separation efficiency. For this study, DL-Ala, DL-Asn, DL-Ser and DL-Pro were selected because their D-forms are candidates for the biomarkers of CKD. This method shows the presence of $0.4-4.8 \%$ for D-Asn, $1.5-16.6 \%$ for D-Ser, $0.3-11.6 \%$ for D-Ala and $0.3-7.1 \%$ for D-Pro, and the correlation between the $\% \mathrm{D}$ values and the eGFR values were observed. The eGFR (estimated Glomerular Filtration Rate) is the best test to measure the level of kidney function and determine the stage of kidney disease. Indeed, these results showed that the more advanced the stage of the disease, the higher the percentage of amino acids in their D-forms. The new 3D-HPLC system has proved to show high selectivity for the chiral analysis of amino acids contained in complex biological matrices as a biomarker for the determination of the disease at different stages [98].

\section{Macrocycle Antibiotic-Based Chiral Stationary Phases}

The complex structure of macrocyclic antibiotics allows for different types of analyte interaction, such as hydrophobic, $\pi-\pi$, dipole-dipole, hydrogen bond, electrostatic, ionic and Van der Waals interactions, due to the high number of stereogenic centres in their structures. Macrocyclic antibiotic-based chiral stationary phases are classed into four groups: ansamycins, polypeptides, glycopeptides and aminoglycosides [84,99]. Recently, a new type of macrocycle antibiotic-based chiral stationary phase was described. Indeed, for this work, two new CSPs, named UHPC-FPP-Titan-Tzwitt and UHPC-SPP-Halo-Tzwitt, were prepared by covalently bonding the glycopeptide teicoplanin chiral selector on zwitterionic columns with different particle diameters (fully- and superficially-porous particles), for the enantioseparation of 31 proteinogenic and non-proteinogenic Fmoc-DLamino acids by liquid chromatography. The performance in terms of separation obtained by both zwitterionic-teicoplanin columns was compared to those obtained from a commercial teicoplanin-based column (Teicoshell) (Table 6). For 26 pairs, the UHPC-SPP-Halo-Tzwitt column offered higher resolutions of separation ranging from Rs (DL-Asn-(Ttr)): 1.15 to Rs (DL-Lys-(Boc)): 10.90. Complementarily, the UHPC-FPP-Titan-Tzwitt column offered the best enantioresolution for Gln and His. Only Cys and Trp-(Boc) enantiomers were better separated with the traditional Teicoshell column. However, DL-Pro and DL-Asp were not separated by any of the three columns. These results prove the influence of the zwitterionic column in combination with a teicoplanin chiral stationary phase. Indeed, both UHPC-FPP-Titan-Tzwitt and UHPC-SPP-Halo-Tzwitt columns offered significantly better resolutions than a commercial teicoplanin-based column. The particle diameters also seem to influence the enantioseparation. Indeed, the morphology differences of fully- and superficially-porous particles (FPP and SPP, respectively) affect the enantioselectivity and the resolution, in favour of the SPP column [100].

\subsubsection{Supercritical Fluid Chromatography}

One- and two-dimensional supercritical fluid chromatography (SFC) are new techniques developed which may be applied in chiral separation [101,102]. In this part, we will consider the polysaccharide- and crown ether-based chiral stationary phases recently used for the chiral separation of amino acids.

\section{Polysaccharide-Based Chiral Stationary Phases}

Recently, Jakubec et al. used nine different chiral columns based on celluloses and amyloses covalently immobilized (Chiralpak IB-3, YMC CHIRAL ART Cellulose SB, Chiralpak IA-3 and YMC CHIRAL ART Amylose SA) or coated (Trefoil CEL-1, Chiralpak OD-3, Lux-CEL1, AMY-1 and Chiralpak AD-3) to study their enantioseparation efficiency under different separation conditions by supercritical fluid chromatography. The best performing column was a Chiralpak OD-3 with methanol $+0.1 \%$ trifluoroacetic acid and $0.1 \%$ diethylamine combined additive separation conditions. The combination of alcohol 
and alkylamine as a co-solvent and a mobile-phase additive seemed beneficial for enantioseparation [103]. Indeed, Lipka et al. optimized their concentration (20-40\% ethanol $+0.3-3.0 \%$ trimethylamine) according to the amino acid enantiomers to be separated using an immobilized cellulose-based CSP (i-Cellulose-5). This column allowed separating some enantiomers of underivatized common and uncommon amino acids (DL-Leu, DL-Ile, DL-Nle, DL-Phe, DL-Ala, DL-Val, DL-Nva, DL-Ser, DL-Car and DL-His) with resolutions ranging from 1.51 (DL-Ser) to 2.24 (DL-Val). This study is promising for pure enantiomers. However, separation conditions could be improved for the separation of a complex amino acid mixture [104].

Table 6. Comparison of Fmoc-amino acid separation performances using the UHPC-FPP-Titan-Tzwitt, UHPC-SPP-HaloTzwitt and Teicoshell columns on MeOH-rich mobile-phase condition.

\begin{tabular}{|c|c|c|c|c|c|c|c|c|}
\hline \multirow{2}{*}{\multicolumn{2}{|c|}{ Samples }} & \multicolumn{6}{|c|}{ Column } & \multirow{3}{*}{ Ref. } \\
\hline & & \multicolumn{2}{|c|}{ UHPC-FPP-Titan-Tzwitt } & \multicolumn{2}{|c|}{ UHPC-SPP-Halo-Tzwitt } & \multicolumn{2}{|c|}{ Teicoshell } & \\
\hline Derivatization & DL-amino acids & Rs & $\alpha$ & Rs & $\alpha$ & Rs & $\alpha$ & \\
\hline \multirow{31}{*}{ Fmoc } & Ala & 8.06 & 1.69 & 9.35 & 2.02 & 4.44 & - & \multirow{31}{*}{ [100] } \\
\hline & Arg & 4.74 & 2.09 & 5.26 & 2.44 & 2.01 & 1.32 & \\
\hline & Arg-(Pbf) & 6.03 & 1.72 & 7.47 & 2.03 & 3.35 & - & \\
\hline & Asn & 2.41 & 1.13 & 2.93 & 1.17 & - & - & \\
\hline & Asn-(Trt) & - & - & 1.15 & 1.07 & - & - & \\
\hline & Asp & - & - & - & 1.02 & - & - & \\
\hline & Asp-(OtBu) & 1.95 & 1.11 & 2.09 & 1.16 & - & - & \\
\hline & Cys & 1.14 & 1.14 & 1.68 & 1.16 & 1.82 & - & \\
\hline & Cys-(Trt) & 1.59 & 1.10 & 2.54 & 1.16 & - & - & \\
\hline & Gln & 7.99 & 1.30 & 4.71 & 1.39 & 1.58 & - & \\
\hline & Gln-(Trt) & 3.23 & 1.22 & 4.46 & 1.32 & 1.96 & - & \\
\hline & Glu & 1.42 & 1.06 & 2.76 & 1.11 & 2.21 & - & \\
\hline & Glu-(OtBu) & 4.28 & 1.49 & 5.99 & 1.64 & 3.34 & - & \\
\hline & His & 3.21 & 1.30 & 3.14 & 1.36 & 1.44 & 1.46 & \\
\hline & His-(Trt) & 4.45 & 1.35 & 5.61 & 1.53 & 3.05 & - & \\
\hline & Ile & 5.33 & 1.43 & 6.43 & 1.70 & 2.18 & - & \\
\hline & Leu & 6.37 & 1.48 & 7.83 & 1.72 & 2.78 & - & \\
\hline & Lys & 3.49 & 1.66 & 4.26 & 2.06 & 2.98 & 1.31 & \\
\hline & Lys-(Boc) & 8.93 & 1.82 & 10.90 & 2.25 & 4.55 & - & \\
\hline & Met & 7.33 & 1.54 & 8.94 & 1.82 & 4.15 & - & \\
\hline & Phe & 4.56 & 1.30 & 5.45 & 1.43 & 2.23 & - & \\
\hline & Pro & - & - & - & - & - & - & \\
\hline & Ser & 2.92 & 1.15 & 3.92 & 1.21 & 2.21 & - & \\
\hline & Ser-(tBu) & 4.30 & 1.27 & 5.54 & 1.41 & 2.35 & - & \\
\hline & Thr & 2.92 & 1.18 & 3.74 & 1.27 & 1.65 & - & \\
\hline & Thr-(tBu) & 1.16 & 1.107 & 1.75 & 1.11 & - & - & \\
\hline & $\operatorname{Trp}$ & 3.07 & 1.19 & 3.91 & 1.29 & 1.97 & - & \\
\hline & Trp-(Boc) & - & - & - & - & 2.93 & - & \\
\hline & Tyr & 3.86 & 1.26 & 4.63 & 1.38 & 2.37 & - & \\
\hline & Tyr-(tBu) & 4.78 & 1.60 & 7.56 & 1.82 & 4.16 & - & \\
\hline & Val & 4.89 & 1.33 & 6.38 & 1.52 & 2.36 & - & \\
\hline
\end{tabular}

\section{Crown Ether-Based Chiral Stationary Phases}

Miller et al. have developed a method for the separation of DL-amino acids enantiomers with a Crownpak CR-I (+) column by supercritical fluid chromatography coupled to mass spectrometry. After optimization of the nature of the mobile phase, this column offered a resolution ranking from Rs (His): 1.99 to Rs (Leu): 9.26 and a short retention times of less than three minutes. With these conditions, all D-amino acid eluted faster to its L-amino acid enantiomer. This method of analysis makes it possible to quickly separate the pure standards of DL-amino acids. However, it can be improved to separate a complex mixture of all of them [105].

\subsubsection{Gas Chromatography}

Gas chromatography is the most-established separation technique for the enantioseparation of amino acid enantiomers. Nevertheless, Schurig et al. reported some chiral 
stationary phases for the enantioseparation of derivatized $\alpha$-amino acids [106]. Recently, only the cyclofructan-based chiral stationary phases was used for the separation of amino acid enantiomers.

\section{Cyclofructan-Based Chiral Stationary Phases}

Xie et al. have summarised the progress on cyclofructan derivatives-based chiral stationary phases for enantioseparation by gas chromatography. Five chiral stationary phases were used for the enantioseparation of DL-amino acids. Two of them-4,6-Di-Opentyl-3-O-trifluoroacetyl cycloinulohexaose-based CSP (CF-CSP4) and 4,6-di-O-pentyl-3O-propionyl cycloinulohexaose-based CSP (CF-CSP5) — were very promising and allowed resolutions ranging from 1.5 to 2.6 for four commons and three uncommon DL-amino acids (Ala, Ile, Leu, Val, allo-Ile, Nle and Nva) to be obtained [107].

\subsubsection{Capillary Electrophoresis}

During 2017 and 2018, Yu et al. summarized several types of chiral selector used for the enantioseparation by capillary electrophoresis. In CE, the chiral selector is added to the buffer solution as a pseudophase, in the same way as the mobile phase in LC. Chiral separation is made possible through non-covalent interactions between the chiral selector and the enantiomers, such as dipole-dipole, hydrogen bond, electrostatic and steric interactions. These chiral selectors can be classed into two categories: low and high molecular mass molecules. Low molecular mass molecules contain ionic liquids and complexes with a central ion. High molecular mass molecules contain the macromolecules such as oligosaccharides (cyclodextrins, polysaccharides), amino acids and nucleic acidbased polymers, and supramolecules such as bile salt micelles. In capillary electrophoresis, chiral selectors can also use as a dual ligand. Dual ligands were created in a combination of immobilized ligands on the surface of the capillary, as a coating, and the addition of free ligands in the buffer solution. In this part, we will further discuss as a chiral selector, two high molecular mass molecules (cyclodextrins and crown ethers) and one low molecular mass molecule (ligand exchange) used recently [108].

\section{Cyclodextrin as a Chiral Selector}

Native $\alpha, \beta, \gamma$-cyclodextrins are made up of six, seven and eight glucose units, respectively, and their derivatives can be used as a chiral selector. The hydrophobic cavity dimensions depend on the nature of the cyclodextrin and can form non-covalent interactions with the chiral analytes [109]. These three standard cyclodextrins and their neutrally (mono-, diand trimethylated and hydroxypropylated) and negatively (sulphated, sulfobutyletherated, succinylated, carboxymethylated, heptakis(6-O-sulfo), hexakis-, heptakis-, octakis(2,3di-O-methyl-6-O-sulfo) and heptakis(2,3-di-O-acetyl-6-O-sulfo) modifications) charged cyclodextrin derivatives were used for the chiral separation of six LL- and DD-dipeptide enantiomers. The type of cyclodextrin concerning cavity size and degree of substitution influenced the enantiomer migration order (EMO). In addition, the composition of the background electrolyte (BGE) as nature and $\mathrm{pH}$ influenced the analysis time. In acidic separation conditions the analysis time was shorter, and the resolution was worsened. In these two studies, neutrally and negatively $\beta$-CDs were shown to be more effective chiral selectors than the $\alpha$ - and $\gamma$-CD derivatives for the enantioseparation of Ala-Phe and the peptide analogues $[110,111]$. The $\gamma$-CD was also used in combination with an ionic liquid (L-Carnitine methyl ester bis(trifluoromethane)sulfonimide, L-CarC1NTf2) as a chiral selector for the enantioseparation of Fmoc-DL-Hcy and Fmoc-DL-Cys. Enantiomeric resolutions obtained for the separation of these pure enantiomers were 6.1 and 6.4, respectively. For the simultaneous separation of these four amino acids derivatized, this method allowed a resolution as high as 4.1 to be obtained for Rs (Hcy): 5.9 and Rs (Cys). This study has not yet been applied to mixtures of biological or more complex compounds [112].

Microchip electrophoresis (MCE) mode can also be used for the enantioseparation of DL-amino acids. Recently, Zhang et al. have used a chiral nematic mesoporous silica 
(CNMS) as the chiral stationary phase in combination with hydroxypropyl- $\beta$-cyclodextrin $(\mathrm{HP}-\beta-\mathrm{CD})$ as the chiral selector for the separation of 10 DL-amino acid pairs. This combination allowed the enantioresolution to be improved to a resolution average of 1.13 , while with the use of only HP- $\beta-C D$, the resolution average for these 10 DL-amino acid enantiomers was 0.68 [113].

\section{Crown Ether as a Chiral Selector}

The most commonly used crown ethers are [18] crown- 6 and its derivatives. Their cavity structure limits chiral separation to primary amines, including amino acids. However, the separation must be performed under pure acidic conditions so that these amines are fully protonated and other cationic species present in the BGE do not interact with the crown ether [109].

Lee et al. have developed a method for the enantioseparation of underivatized free amino acids using $(+)-$ and $(-)-18 \mathrm{C} 6 \mathrm{H} 4$ as a chiral selector [114]. This method allows separating all DL-amino acids, except DL-Pro and DL-Asn, with a resolution ranking from $\operatorname{Rs}(\mathrm{Cys}): 0.5$ to $\operatorname{Rs}(\mathrm{Ser}): 21.0$. Concerning the migration order for amino acids, the L-amino acids migrated faster than their analog D-amino acid counterparts except for Ser, Thr and Met. This method shows promise for the separation of amino acid enantiomers. However, some improvements can be made for the resolution of separation of DL-Cys (Rs: 0.5), DL-Ala (Rs: 0.7) and DL-Glu (Rs: 0.8).

\section{Ligand Exchange as a Chiral Selector}

Chiral ligand exchange capillary electrochromatography (CLE-CEC) using a central ion has been recently used for enantioseparation of derivatized or underivatized DL-amino acids. First, Zn (II) was used as a central ion for the enantioseparation of Dns-DL-amino acid enantiomers. For this amino acid separation, the authors have used four chiral DL-oligopeptides based on lysine residues as ligands to form [((Gly)-Lys $\mathrm{x}) \mathrm{Zn}$ (II)(AA)] complexes. The migration order of Dns-DL-amino acid analytes has been influenced by the nature of the chiral ligand employed. Indeed, when the Gly-D-Lys ligand was used, the Dns-L-amino acid had a faster retention time than the Dns-D-amino acid analyte. Chiral dipeptide ligands, Gly-L-Lys and Gly-D-Lys, allow for a better separation of Dns-DL-amino acid enantiomers with a resolution greater than 2 , than other ligands ( (L-Lys) $\left.)_{2}-\mathrm{OH}\right)$ and $\left((\mathrm{L}-\mathrm{Lys})_{4}-\mathrm{OH}\right)$ with a resolution below 1 . This new method shows the great potential of dipeptides as ligands in the CLE-CEC separation of DL-amino acid enantiomers and can be developed for the separation of complex biological samples [115]. In another study, Feng et al. used different synthetic copolymer dual ligands as chiral ligands to form [(P(MAn-St-MAX) Zn (II)(AA)] complexes. The use of the free chiral ligands and immobilized ligands alone do not allow for separation of the DL-amino acids enantiomers, while the dual ligands have offered a good separation (Figure 7). With the dual ligand system, resolutions ranged from 1.67 to 3.45 for Ala, Gln, Ile, Tyr, Asn, Met and Ser. For other amino acids, including Asp, Trp, Leu, Phe and Thr, their resolutions were lower and are ranked from 0.55 to 1.19. DL-Pro and DL-Val were not separated. Among the four synthesized copolymer dual chiral ligands, the best results were obtained with the poly maleic anhydride-co-styrene-co-N-methacryloyl-L-histidine methyl ester [P(MAn-StMAH)] [116].

$\mathrm{Cu}$ (II) was also used as a central ion in complexation with L-His to create the [Cu (II)-L-His] complex with $\beta$-cyclodextrin $(\beta$-CD) as a dual chiral selector for the enantioseparation of DL-Trp, DL-Tyr and DL-Phe by capillary electrophoresis. For this study, several concentrations of $\mathrm{Cu}$ (II), L-His and $\beta$-CD were tested at different $\mathrm{pH}$ and voltages. Each pair of enantiomers was separated in 20 minutes with a resolution ranging from 3.6 to 6.1. For DL-Phe and DL-Trp, the EMO was similar to the L-enantiomer and eluted faster than its counterpart. Both peaks from the separation of D- and L-Tyr were not identified [117]. 


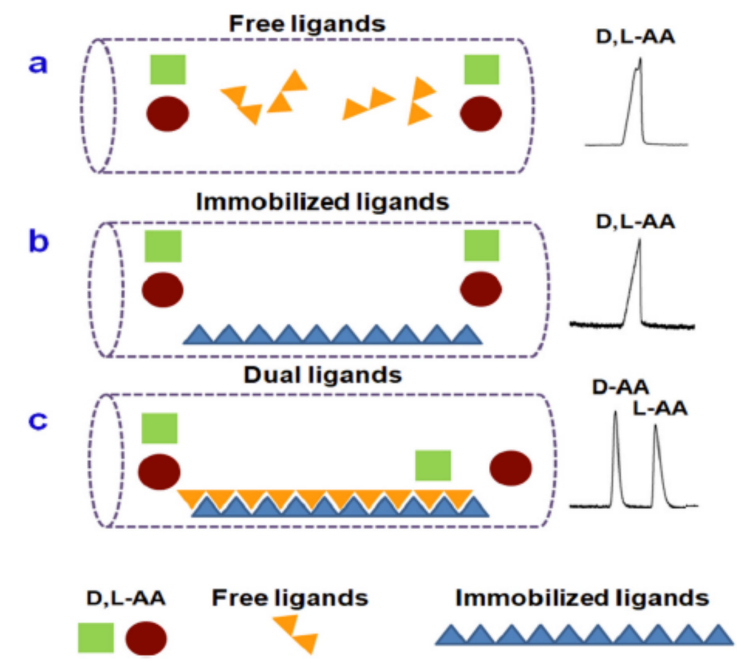

Figure 7. Illustration of enantioseparation mechanism of CLE-CEC by using (a) free ligand alone, (b) immobilized ligand alone and (c) dual ligands. Reproduced with permission from the authors of [116].

Micellar Electrokinetic Chromatography (MEKC)

Micellar electrokinetic chromatography is another capillary electrophoresis mode using a high concentration of micelles. Recently, Evans et al. have analyzed 36 primary amines including D- and L-amino acids derivatized with 2,3-naphthalenedicarboxaldehyde and separated by MEKC using sodium dodecyl sulfate and sodium deoxycholate as surfactants. Then, the authors applied this method for the enantioseparation of DL-Ser at low nanomolar concentrations containing in the endocrine portion of the pancreas, the islets of Langerhans. In the study, the successful separation of D-Ser to its counterpart has an important interest due to its agonist activity for the ionotropic N-methyl-D-aspartate receptors [118].

\subsubsection{Comparison of Different Techniques}

Among chromatographic and electrophoresis techniques previously described, the most efficient of them, in terms of chiral separation performances (resolution and separation factor), were summarized in Table 7 . The crown ether used as chiral stationary phase or added to BGE was preferably used for the enantioseparation of complex mixtures of amino acids. Furthermore, in liquid chromatography, zwitterionic-exchange- and macrocycle antibiotic-based chiral stationary phase also offered an excellent separation for a similar complex mixture of DL-amino acids. Although gas chromatography is rarely used for the chiral separation of amino acids, the cyclofructan-based chiral stationary phase (CF-CSP5) provided sufficient separation performance.

Regarding the enantioseparation of small peptides, the crown-ether (Table 4) ionexchange and zwitterionic (Table 5) chiral stationary phases were used in liquid chromatography. The results proved that the Crownpak CR-I (+) column offered a better average resolution (Rs: 5.12).

\subsection{Indirect Method}

The indirect method consists of using the derivatization reaction on racemic compounds with a pure chiral reagent, thus resulting in the formation of a pair of diastereomers which can be separated by a chiral or achiral column. The derivatization reaction must be at room temperature to avoid racemization. This method is usually used to facilitate the isolation of the analyte from the biological matrix. In this review, we will summarize the derivatization reagents used recently for the enantioseparation of amino acids and newly synthesized derivatization reagents. Among derivatization reagents that have been used recently, most of them react with the N-terminus of amino acids, and they 
were commercial $((+)$ - or (-)-1-(9-fluorenyl)ethyl chloroformate) $((+)$ - or (-)-FLEC) and $\mathrm{N}$-(4-Nitrophenoxycarbonyl)-L-phenylalanine 2-methoxyethyl ester (S-NIFE)) or synthetic $((R)$ - or $(S)$-4-nitrophenyl-N-[2-(diethylamino)-6,6-dimethyl-[1,1-biphenyl]-2-yl] carbamate hydrochloride $((R)$ - or $(S)$-BiAC) and N-[1-oxo-5-(triphenylphosphonium) pentyl]-(R)-1,3thiazolidinyl-4-N-hydroxysuccinimide ester bromide salt (OTPTHE)).

Table 7. Summary of the most efficient techniques for enantioseparation of underivatized DL-amino acids.

\begin{tabular}{|c|c|c|c|c|c|}
\hline Techniques & CSP & Columns & Analytes & Rs and/or $\alpha$ Average & Ref. \\
\hline \multirow[t]{3}{*}{$\begin{array}{c}\text { Liquid } \\
\text { chromatography }\end{array}$} & Crown-ether & Cronwpak CR-I (+) & 21 DL-amino acids & $\begin{array}{c}\text { Rs: } 5.12 \\
(\min .1 .49, \text { max. } 8.90)\end{array}$ & [80] \\
\hline & Zwitterrionic & Chiralpak ZWIX (+) & 21 DL-amino acids & $\begin{array}{c}\alpha: 2.33 \\
(\min .1 .26, \max .5 .31)\end{array}$ & [93] \\
\hline & Macrocycle antibiotic & UHPC-SPP-Halo-Tzwitt & 28 DL-amino acids & $\begin{array}{c}\text { Rs: } 5.01 \\
\text { (min. 1.15, max. 10.90) } \\
\alpha: 1.52 \\
\text { (min. 1.02, max. 2.44) }\end{array}$ & [100] \\
\hline $\begin{array}{l}\text { Supercritical fluid } \\
\text { chromatography }\end{array}$ & Crown-ether & Crownpak CR-I (+) & 18 DL-amino acids & $\begin{array}{c}\text { Rs: } 5.27 \\
\text { (min. 1.99, max. 9.26) }\end{array}$ & [105] \\
\hline Gas chromatography & Cyclofructan & CF-CSP5 & 7 DL-amino acids & $\begin{array}{c}\text { Rs: } 1.81 \\
\text { (min. 1.50, max. 2.60) } \\
\alpha: 1.04 \\
\text { (min. 1.03, max. 1.06) }\end{array}$ & [107] \\
\hline $\begin{array}{l}\text { Capillary } \\
\text { electrophoresis }\end{array}$ & Crown-ether & BGE containing $18 \mathrm{C} 6 \mathrm{H} 4$ & 18 DL-amino acids & $\begin{array}{c}\text { Rs: } 2.97 \\
\text { (min. } 0.70, \max .21 .00) \\
\alpha: 1.03 \\
\text { (min. 1.01, max. 1.22) }\end{array}$ & [114] \\
\hline
\end{tabular}

The more popular commercial derivatization reagents were the (+)- and (-)-FLEC. Indeed, Moldovan et al. used these reagents in their both undifferentiated forms as chiral derivatization reagents for the enantioseparation of 19 amino acid pair of diastereomers by RP-HPLC coupled to mass spectrometry with diphenyl and biphenyl stationary phases [119]. The average resolution for each amino acid pairs was 2.9 and 2.3 for the diphenyl and biphenyl stationary phases respectively, under optimal separation conditions. Indeed, with diphenyl stationary phase, 14 of 19 amino acid pair of enantiomers (except

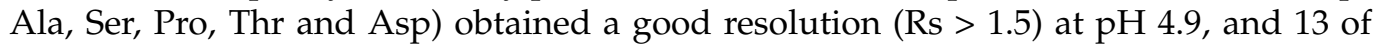
19 amino acid pair of diatereoisomers (except Ala, Ser, Pro, Thr, Asp and Glu) at pH 4.2. Both columns allow DL-amino acids to be separated with the same elution order with D-derivative first respectively at $\mathrm{pH} 4.9$ and 4.2. However, the authors observed a reversal in the elution order with L-form eluted first at pH 2.5 and 7. These two methods allow separating pure FLEC-DL-amino acid enantiomers in less than 30 minutes. This short time does not allow separating a complex mixture of amino acids, because the retention times are very near. Furthermore, (+)-FLEC was used by Pérez-Míguez et al. where a TIMS-TOFMS method was developed for the analysis of 21 common and uncommon (+)-FLEC-DL-amino acid enantiomers [120]. With this new method, 17 were separated separately at different voltage ramps. Then, the enantioseparation of several (+)-FLEC-DL-amino acids in one run was tested. For this work, three groups of four (+)-FLEC-DL-amino acids were used with one voltage ramp applied per group. The first group consisted of Orn, Lys, His and Tyr with voltage ramps ranging from 135 to $170 \mathrm{~V}$; Asn, Ser, Pipe and Gln at 100-130V for the second group; and Met, Phe, SeMet and Arg at 109-135 V for the last group. For each group, some amino acids have co-migrated. Their distinction was possible thanks to their respective $\mathrm{m} / \mathrm{z}$ (Figure 8). This method allowed Ser and Asp separation with a better resolution than the previous study. 

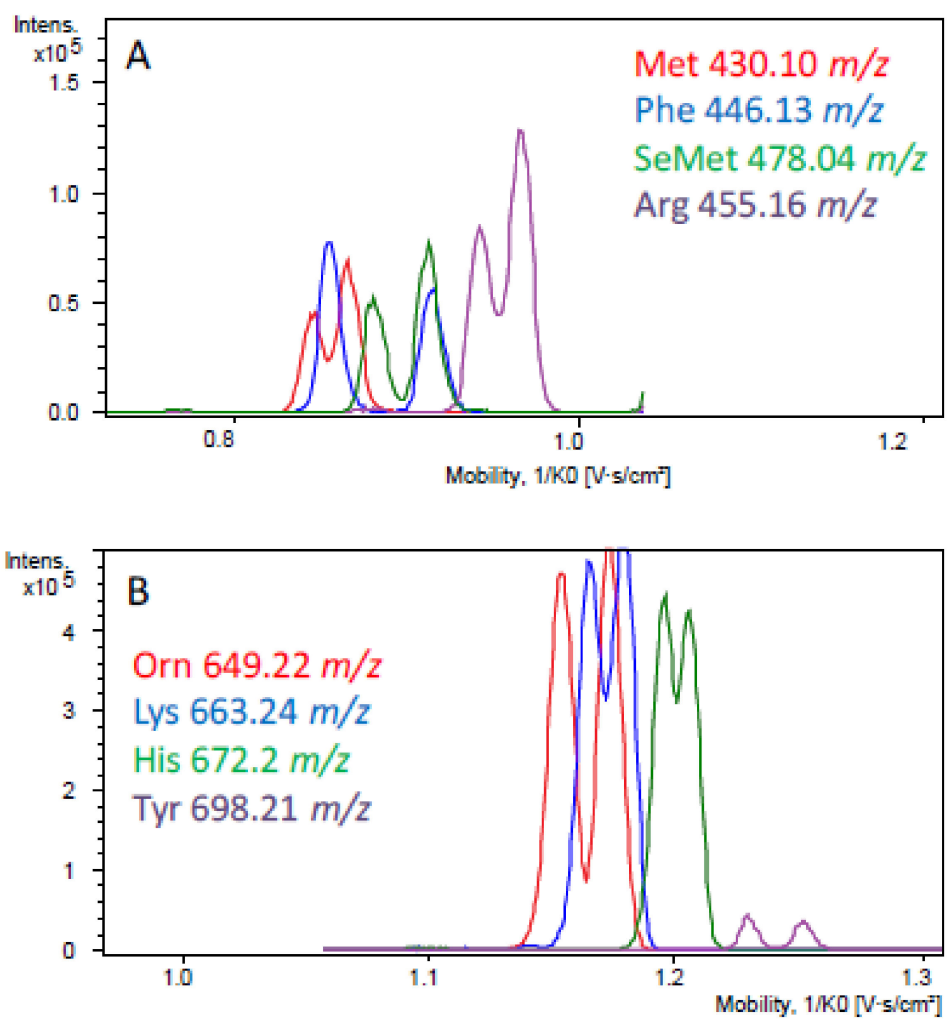

Figure 8. TIMS-TOFMS of FLEC-AA mixtures using a voltage ramp of (A) 109-135 V and (B) 135-170 V in $510 \mathrm{~ms}$. Reproduced with permission from the authors of [120].

The commercial S-NIFE derivatized reagent, as far as it is concerned, was used by Danielsen et al. which have developed a method for the determination of L- and D-amino acid ratios contained in complex protein matrices using LC-MS/MS analysis. Protein and standard amino acids were hydrolyzed by $\mathrm{DCl}$ following two methods: in glass capillaries and vacuum hydrolysis tubes. In this case, deuterated hydrolysis has been used to eliminate the $\mathrm{L}$ - and $\mathrm{D}$-amino acid racemization ratio due to the natural conversion. These two hydrolysis methods allow determining the rate of $0.30 \%$ and $0.25 \% \mathrm{D}$-amino acids, respectively, contained in $\alpha$-lactalbumin protein. Their exact positions on the protein sequence were not determined [66].

Other derivatization reagents can be synthesized to react with the $\mathrm{N}$-terminus of amino acids. Historically, the axially chiral hydrophobic derivatizing reagent was developed for the analysis of amine and alcohol diastereoisomers by normal-phase liquid chromatography $[121,122]$. However, for the axial derivatization for hydrophilic compounds, such as amino acids, a new derivatization reagent was necessary to be developed. Recently, Harada et al. have developed biaryl axially derivatives, $(R)$-4-nitrophenyl N-[2'-(diethylamino)-6,6'dimethyl-[1,1'-biphenyl]-2-yl] carbamate hydrochloride $((R)$-BiAC), as a new axially chiral derivatizing reagent for the enantioseparation of proteinogenic amino acids by RP-HPLCMS/MS. This new chiral derivatizing reagent allowed all DL-amino acids to be separated within 11.5 minutes with a resolution greater than 1.9, except for complex mixtures, such as threonine mixture (DL-Thr and DL-allo-Thr), and leucine-isoleucine mixture (DL-Leu, DL-Ile and DL-allo-Ile) [123]. The same authors applied this new derivatizing reagent $((R)$ $\mathrm{BiAC}$ ) on DL-amino acids in human urine for their simultaneous determination by liquid chromatography electrospray ionization tandem mass spectrometry. After optimization of separation conditions, 36 DL-amino acids and glycine were separated in 20 minutes with good resolution. These results were verified using the opposite chiral derivatizing reagent $(S)$-BiAC. Using (S)-BiAC causes the inversion of the migration order of D- and L-amino acids. The concentration of each amino acid was determined by LC-MS. The $(S)-\mathrm{BiAC} /(R)-$ 
BiAC ratio of amino acid concentration was higher ( $>84 \%)$, except for D-allo-Ile $(67 \%)$ and for D-Asp, D-Pro, D-Trp and L-Asp whose peaks were below the limit of quantification (LOQ) with both chiral derivatizing reagents. This method is promising for simultaneous analysis of DL-amino acids in biological samples (Figure 9). In this case, the quantification of D-amino acids in human urine can be used as a biomarker to screen for chronic kidney disease [124].

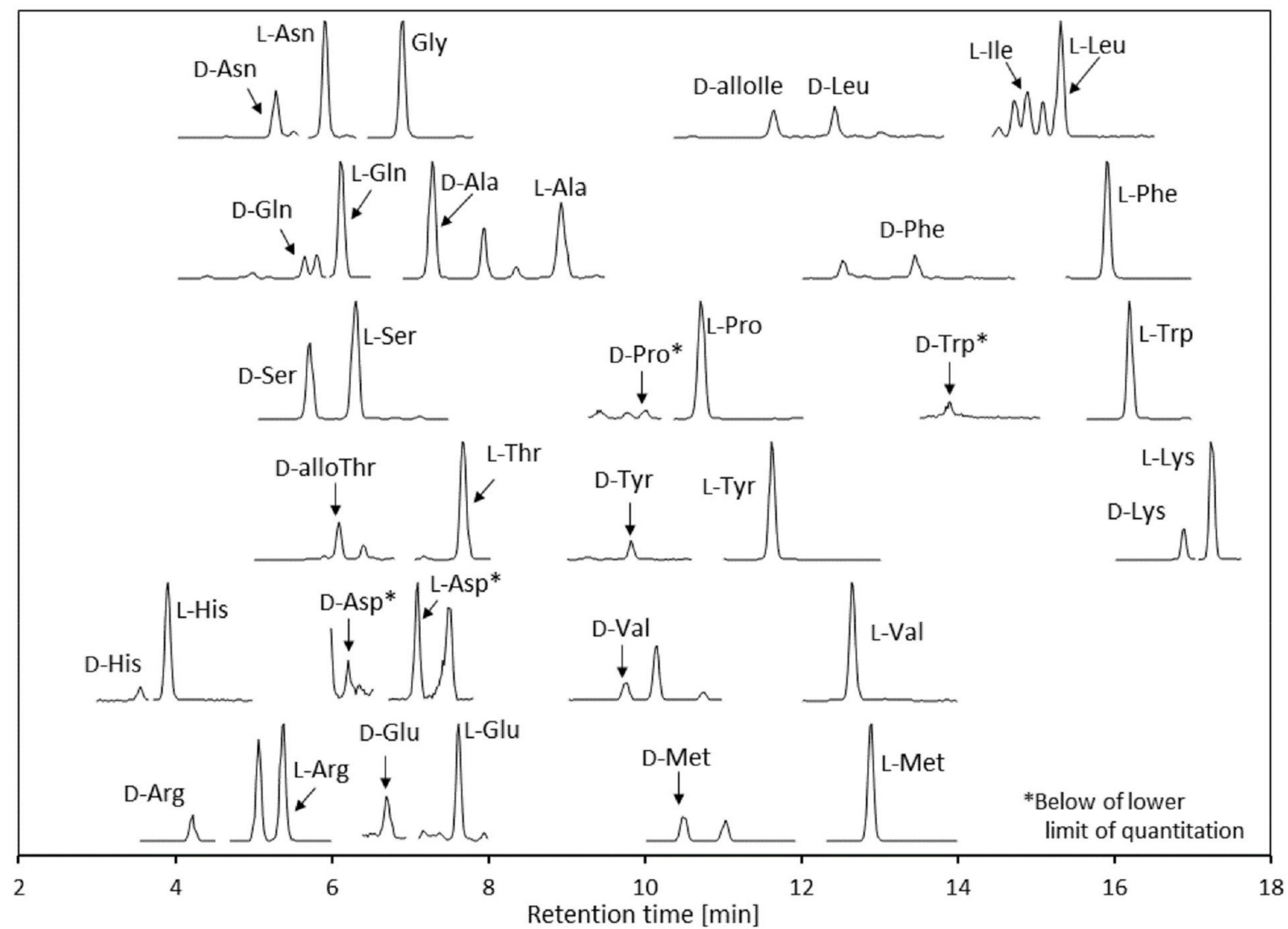

Figure 9. Chromatograms of D- and L-amino acids and glycine in human urine sample. Reproduced with permission from the authors of [124].

Another group has synthesized a new derivatization reagent N-[1-oxo-5-(tripheny lphosphonium) pentyl] -(R)-1,3-thiazolidinyl-4-N-hydroxysuccinimide ester bromide salt (OTPTHE) for the enantioseparation of DL-Ser from human plasma by liquid chromatography coupled to mass spectrometry. This reagent first was tested for the separation of 13 DL-amino acids in $22 \mathrm{~min}$, with the resolution from Rs (Thr): 1.62 to Rs (Pro): 2.51 . This derivatization method was applied to analyzed DL-Ser from the plasma of 10 healthy volunteers with a similar resolution. The authors do not show the results for the other amino acids contained in the human plasma [125].

Derivatization mainly takes place on the terminal amine of the amino acid, which makes it possible to study all amino acids simultaneously. However, it is possible to derivatize the amino acid with another functional group to allow for more selective analysis. Thiols naturally occur in their reduced or oxidized forms. The tripeptide, glutathione, is found in both of these forms and is primarily studied as a biomarker for the assessment of oxidative stress. Russo et al. compared two cell-permeable commercial derivatizing agents-N-ethyl maleimide (NEM) and (R)-(+)-N-(1-phenylethyl) maleimide (NPEM) - for derivatization of biological thiols using a biphenyl reversed-phase liquid chromatographyhigh-resolution mass spectrometry (LCHRMS). Four biological thiols were used for the evaluation: cysteine (Cys), homocysteine (Hcy), N-acetylcysteine (NAC) and glutathione (GSH). The derivatization efficiency of Cys and their derivatives by NEM and NPEM was 
$97 \%$ and $100 \%$, respectively. NPEM also allowed for the enhancement of ESI ionization. However, it was more prone to experience side reactions, such as derivatization of amines and opening of the cycle, and it is more sensible to $\mathrm{pH}$ variation, compared to NEM. For cellpermeable thiol-protecting reagent used on mild derivatizing conditions to minimize the impact on the cellular structure and avoid artificial changes in metabolite concentrations, NEM seems to be better than NPEM [126].

\section{Concluding Remarks and Prospects}

Homochirality is omnipresent in proteins as much by the D- and L-amino acid enantiomers as by the $\mathrm{D}$ - and L-oligosaccharide enantiomers as post-translational modifications. The natural conversion of $\mathrm{L} / \mathrm{D}$-amino acids in proteins takes place in a nonuniform manner. Thus, it is necessary to examine the chirality of each amino acid in the proteinogenic sequence. For this determination, sequence-dependent and sequence-independent strategies are possible. The sequence-dependent strategy can be applied with two different methods. First, the protein is digested by an enzyme and each peptide obtained was identified on the protein sequence by mass spectrometry analysis. Then, these peptides were hydrolyzed on amino acid and then react with a standard protected amino acid, such as Boc-L-Cys or BocL-Leu as an example. This method allows the LL- and DL-dipeptides formed, which have different retention times, to be distinguished. The second consists of digesting the protein by a specific enzyme. Various enzymes are enantioselective such as: endoproteinase Asn-N, L-isoaspartyl methyltransferase, D-aspartyl endoproteinase and glutamyl endoproteinase Glu-C, which recognise only L- $\alpha$-Asp, L- $\beta$-Asp, D- $\alpha$-Asp and L-Glu, respectively. The sequence-independent strategy, as far as it is concerned, consists of hydrolyzing the protein under acidic conditions. The use of deuterated or tritiated hydrochloric acid in heavy water exchanges the hydrogen on the alpha carbon on free amino acid with a deuterium or tritium atom and limits the natural racemization. Although liquid chromatography is widely used for the determination of D-amino acids, other separation techniques are also used. Some chromatographic and electrophoretic techniques using commercial or synthetic chiral stationary phases can be used for the enantioseparation of free amino acids and peptides. Among these chiral stationary phases, the most recently used was based on polysaccharides, cyclodextrins, crown-ethers, Brush-types, ion- and zwitterion-exchange, macrocycle antibiotics, cyclofructans and ligand exchange. The comparative study of these different chiral stationary phases showed, in terms of separation performance, that the Crownpak CR-I (+) column offered the best separation of DL-amino acid and small peptide enantiomers. Another enantioseparation technique is based on a derivatization reaction with a pure chiral compound on the free amino acids. Although the majority of commercial $((+)$ - or $(-)$-FLEC and S-NIFE) or synthetic $((R)$ - or $(S)$-BiAC and OTPTHE) derivatization reagents reaction on the $\mathrm{N}$-terminus of amino acids, some chiral reagents were developed to react with another amino acid functional group for more selective analysis, like NEM and NPEM reagents on cysteine thiol functions. For future work, given the many possibilities, new chiral stationary phases and derivatization reagents can be developed and applied to different proteins with important biological functions. This will make it possible to discover other D-amino acids and their position on the proteinogenic sequence and their occurrence on human health and disease.

Funding: This research was funded by Czech Science Foundation, grant number 20-03899S.

Conflicts of Interest: The authors declare no conflict of interest. The funders had no role in the design of the study; in the collection, analyses, or interpretation of data; in the writing of the manuscript, or in the decision to publish the results.

\section{References}

1. Qi, X.; Tester, R.F. Fructose, Galactose and Glucose-In Health and Disease. Nutr. ESPEN 2019, 33, 18-28. [CrossRef]

2. Qi, X.; Tester, R.F. Lactose, Maltose, and Sucrose in Health and Disease. Nutr. Food Res. 2020, 64, 1901082-1901091. [CrossRef] [PubMed] 
3. Sajadimajd, S.; Bahrami, G.; Daglia, M.; Nabavi, S.M.; Naseri, R.; Farzaei, M.H. Plant-Derived Supplementary Carbohydrates, Polysaccharides and Oligosaccharides in Management of Diabetes Mellitus: A Comprehensive Review. Food Rev. Int. 2019, 35, 563-586. [CrossRef]

4. Reily, C.; Stewart, T.J.; Renfrow, M.B.; Novak, J. Glycosylation in Health and Disease. Nat. Rev. Nephrol. 2019, 15, 346-366. [CrossRef]

5. He, B.L.; Lloyd, D.K. Chiral Methods. In Specification of Drug Substances and Products, 2nd ed.; Riley, C.M., Rosanske, T.W., Reid, G., Eds.; Elsevier: Amsterdam, The Netherlands, 2020; pp. 425-458, ISBN 9780081028247.

6. Annavarapu, S.; Nanda, V. Mirrors in the PDB: Left-Handed $\alpha$-Turns Guide Design with D-amino Acids. BMC Struct. Biol. 2009, 9, 61-74. [CrossRef]

7. Grieco, P.; Carotenuto, A.; Auriemma, L.; Saviello, M.R.; Campiglia, P.; Gomez-Monterrey, I.M.; Marcellini, L.; Luca, V.; Barra, D.; Novellino, E.; et al. The effect of D-amino acid substitution on the selectivity of temporin L towards target cells: Identification of a potent anti-Candida peptide. Biochim. Biophys. Acta Biomembr. 2013, 1828, 652-660. [CrossRef]

8. Gößler-Schöfberger, R.; Hesser, G.; Reif, M.M.; Friedmann, J.; Duscher, B.; Toca-Herrera, J.L.; Oostenbrink, C.; Jilek, A. A stereochemical switch in the aDrs model system, a candidate for a functional amyloid. Arch. Biochem. Biophys. 2012, 522, 100-106. [CrossRef]

9. Fujii, N.; Fujii, N.; Kida, M.; Kinouchi, T. Influence of L $\beta$-, D $\alpha$ - and D $\beta$-Asp Isomers of the Asp-76 Residue on the Properties of AA-Crystallin 70-88 Peptide. Amino Acids 2010, 39, 1393-1399. [CrossRef] [PubMed]

10. Fujii, N.; Saito, T. Homochirality and Life. Chem. Rec. 2004, 4, 267-278. [CrossRef] [PubMed]

11. Fujii, N. D-amino Acid in Elderly Tissues. Biol. Pharm. Bull. 2005, 28, 1585-1589. [CrossRef] [PubMed]

12. Fujii, N.; Kawaguchi, T.; Sasaki, H.; Fujii, N. Simultaneous Stereoinversion and Isomerization at the Asp-4 Residue in $\beta B 2-$ Crystallin from the Aged Human Eye Lenses. Biochemistry 2011, 50, 8628-8635. [CrossRef]

13. Fujji, N.; Takata, T.; Fujii, N.; Aki, K.; Sakaue, H. D-amino Acids in Protein: The Mirror of Life as a Molecular Index of Aging. Biochim. Biophys. Acta Proteins Proteom. 2018, 1866, 840-847. [CrossRef]

14. Miyamoto, T.; Homma, H. Detection and Quantification of D-amino Acid Residues in Peptides and Proteins Using Acid Hydrolysis. Biochim. Biophys. Acta Proteins Proteom. 2018, 1866, 775-782. [CrossRef]

15. Ha, S.; Kinouchi, T.; Fujii, N. Age-Related Isomerization of Asp in Human Immunoglobulin G Kappa Chain. Biochim. Biophys. Acta Proteins Proteom. 2020, 1868, 140410-140417. [CrossRef]

16. Bastings, J.J.A.J.; van Eijk, H.M.; Olde Damink, S.W.; Rensen, S.S. D-amino Acids in Health and Disease: A Focus on Cancer. Nutients 2019, 11, 2205. [CrossRef]

17. Kuwada, M.; Teramoto, T.; Kumagaye, K.Y.; Nakajima, K.; Watanabe, T.; Kawai, T.; Kawahami, Y.; Niidome, T.; Sawada, K.; Nishizawa, Y.; et al. $\omega$-Agatoxin-TK Containing D-Serine at Position 46, but Not Synthetic $\omega$-[L-Ser]Agatoxin-TK, Exerts Blockade of P-Type Calcium Channels in Cerebellar Purkinje Neurons. Mol. Pharmacol. 1994, 46, 587-593.

18. Richter, G.; Egger, R.; Kreil, G. D-Alanine in the Frog Skin Peptide Dermorphin Is Derived from L-Alanine in the Precursor. Science 1987, 238, 200-202. [CrossRef] [PubMed]

19. Pavithrra, G.; Rajasekaran, R. Gramicidin Peptide to Combat Antibiotic Resistance: A Review. Int. J. Pept. Res. Ther. 2020, 26, 191-199. [CrossRef]

20. Fujii, N.; Satoh, K.; Harada, K.; Ishibashi, Y. Simultaneous Stereoinversion and Isomerization at Specific Aspartic Acid Residues in OrA-Crystallin from Human Lens. J. Biochem. 1994, 116, 663-669. [CrossRef]

21. Hooi, M.Y.S.; Truscott, R.J.W. Racemisation and Human Cataract. D-Ser, d-Asp/Asn and d-Thr Are Higher in the Lifelong Proteins of Cataract Lenses than in Age-Matched Normal Lenses. Age 2011, 33, 131-141. [CrossRef]

22. Hooi, M.Y.S.; Raftery, M.J.; Truscott, R.J.W. Accelerated Aging of Asp 58 in AA Crystallin and Human Cataract Formation. Exp. Eye Res. 2013, 106, 34-39. [CrossRef] [PubMed]

23. Wu, H.-T.; Julian, R.R. Two-Dimensional Identification and Localization of Isomers in Crystallin Peptides Using TWIM-MS. Analyst 2020, 145, 5232-5341. [CrossRef] [PubMed]

24. Fujii, N.; Takata, T.; Kim, I.; Morishima, K.; Inoue, R.; Magami, K.; Matsubara, T.; Sugiyama, M.; Koide, T. Asp Isomerization Increases Aggregation of $\alpha$-Crystallin and Decreases Its Chaperone Activity in Human Lens of Various Ages. Biochim. Biophys. Acta Proteins Proteom. 2020, 1868, 140446-140457. [CrossRef] [PubMed]

25. Masuda, W.; Nouso, C.; Kitamura, C.; Terashita, M.; Noguchi, T. D-Aspartic Acid in Bovine Dentine Non-Collagenous Phophoprotein. Arch. Oral Biol. 2002, 47, 757-762. [CrossRef]

26. Powell, J.T.; Vine, N.; Crossman, M. On the Accumulation of D-Aspartate in Elastin and Other Proteins of the Ageing Aorta. Atherosclerosis 1992, 97, 201-208. [CrossRef]

27. Ritz-Timme, S.; Laumeier, I.; Collins, M.J. Aspartic Acid Racemization: Evidence for Marked Longevity of Elastin in Human Skin. Br. J. Dermatol. 2003, 149, 951-959. [CrossRef]

28. Ishigo, S.; Negishi, E.; Miyoshi, Y.; Onigahara, H.; Mita, M.; Miyamoto, T.; Masaki, H.; Homma, H.; Ueda, T.; Hamase, K. Establishment of a Two-Dimensional HPLC-MS/MS Method Combined with DCL/D2O Hydrolysis for the Determination of Trace Amounts of D-amino Acid Residues in Proteins. Chromatography 2015, 36, 45-50. [CrossRef]

29. Friedrich, M.G.; Hancock, S.E.; Raftery, M.J.; Truscott, R.J.W. Isoaspartic Acid Is Present at Specific Sites in Myelin Basic Protein from Multiple Sclerosis Patients: Could This Represent a Trigger for Disease Onset? Acta Neuropathol. Commun. 2016, 4, 83-95. [CrossRef] 
30. Fujii, N.; Ishibashi, Y.; Satoh, K.; Fujino, M.; Harada, K. Simultaneous racemization and isomerization at specific aspartic acid residues in $\alpha$ B-crystallin from the aged human lens. Biochim. Biophys. Acta 1994, 1204, 157-163. [CrossRef]

31. Livnat, I.; Tai, H.-G.; Jansson, E.T.; Bai, L.; Romanova, E.V.; Chen, T.-T.; Yu, K.; Chen, S.-A.; Zhang, Y.; Wang, Z.-Y.; et al. A D-amino Acid-Containing Neuropeptide Discovery Funnel. Anal. Chem. 2016, 88, 11868-11876. [CrossRef]

32. Young, G.W.; Hoofring, S.A.; Mamula, M.J.; Doyle, H.A.; Bunick, G.J.; Hu, Y.; Aswad, D.W. Protein L-Isoaspartyl Methyltransferase Catalyzes In Vivo Racemization of Aspartate-25 in Mammalian Histone H2B. J. Biol. Chem. 2005, 280, 26094-26098. [CrossRef]

33. Ritz, S.; Turzynski, A.; Schütz, H.W.; Hollmann, A.; Rochholz, G. Identification of Osteocalcin as a Permanent Aging Constituent of the Bone Matrix: Basis for an Accurate Age at Death Determination. Forensic Sci. Int. 1996, 77, 13-26. [CrossRef]

34. Kawamura, I.; Mijiddorj, B.; Kayano, Y.; Matsuo, Y.; Ozawa, Y.; Ueda, K.; Sato, H. Separation of D-amino Acid-Containing Peptide Phenylseptin Using 3,3'-Phenyl-1,1'-Binaphthyl-18-Crown-6-Ether Columns. Biochim. Biophys. Acta Proteins Proteom. 2020, 1868, 140429-140436. [CrossRef] [PubMed]

35. Roher, A.E.; Lowenson, J.D.; Clarke, S.; Wolkow, C.; Wang, R.; Cotter, R.J.; Reardon, I.M.; Zürcher-Neely, H.A.; Heinrikson, R.L.; Ball, M.J.; et al. Structural Alterations in the Peptide Backbone of Beta-Amyloid Core Protein May Account for Its Deposition and Stability in Alzheimer's Disease. J. Biol. Chem. 1993, 268, 3072-3083. [CrossRef]

36. Kaneko, I.; Yamada, N.; Sakuraba, Y.; Kamenosono, M.; Tutumi, S. Suppression of Mitochondrial Succinate Dehydrogenase, a Primary Target of $\beta$-Amyloid, and Its Derivative Racemized at Ser Residue. J. Neurochem. 1995, 65, 2585-2593. [CrossRef]

37. Zhang, J.; Yip, H.; Katta, V. Identification of Isomerization and Racemization of Aspartate in the Asp-Asp Motifs of a Therapeutic Protein. Anal. Biochem. 2011, 410, 234-243. [CrossRef]

38. Mijiddorj, B.; Kaneda, S.; Sato, H.; Kitahashi, Y.; Javkhlantugs, N.; Naito, A.; Ueda, K.; Kawamura, I. The Role of d-Allo-Isoleucine in the Deposition of the Anti-Leishmania Peptide Bombinin H4 as Revealed by 31 P Solid-State NMR, VCD Spectroscopy, and MD Simulation. Biochim. Biophys. Acta Proteins Proteom. 2018, 1866, 789-798. [CrossRef] [PubMed]

39. Gause, G.F. Gramicidin $S$ review of recent work. Lancet 1946, 248, 46-47. [CrossRef]

40. Yan, Y.; Wei, H.; Fu, Y.; Jusuf, S.; Zeng, M.; Ludwig, R.; Krystek, S.R., Jr.; Chen, G.; Tao, L.; Das, T.K. Isomerization and Oxidation in the Complementarity-Determining Regions of a Monoclonal Antibody: A Study of the Modification-Structure-Function Correlations by Hydrogen-Deuterium Exchange Mass Spectrometry. Anal. Chem. 2016, 88, 2041-2050. [CrossRef] [PubMed]

41. Soyez, D.; Laverdure, A.-M.; Kallen, J.; van Herp, F. Demonstration of a Cell-Specific Isomerization of Invertebrate Neuropeptides. Neuroscience 1997, 82, 935-942. [CrossRef]

42. Jimenéz, E.C.; Olivera, B.M.; Gray, W.R.; Cruz, L.J. Contryphan Is a D-Tryptophan-Containing Conus Peptide. J. Biol. Chem. 1996, 271, 28002-28005. [CrossRef] [PubMed]

43. Erspamer, V.; Melchiorri, P.; Falconieri-Erspamer, G.; Negri, L.; Corsi, R.; Severini, C.; Barra, D.; Simmaco, M.; Kreil, G. Deltorphins: A Family of Naturally Occurring Peptides with High Affinity and Selectivity for 6 Opioid Binding Sites. Proc. Natl. Acad. Sci. USA 1989, 86, 5188-5192. [CrossRef] [PubMed]

44. Mor, A.; Delfour, A.; Sagan, S.; Amiche, M.; Pradelles, P.; Rossier, J.; Nicolas, P. Isolation of Dermenkephalin from Amphibian Skin, a High-Affinity ( $\delta$-Selective Opioid Heptapeptide Containing a D-amino Acid Residue. FEBS Lett. 1989, 255, 269-274. [CrossRef]

45. Cloos, P.A.C.; Fledelius, C. Collagen Fragments in Urine Derived from Bone Resorption Are Highly Racemized and Isomerized: A Biological Clock of Protein Aging with Clinical Potential. Biochem. J. 2000, 345, 473-480. [CrossRef] [PubMed]

46. Ohta, N.; Kubota, I.; Takao, T.; Shimonishi, Y.; Yasuda-Kamatani, Y.; Minakata, H.; Nomoto, K.; Muneoka, Y.; Kobayashi, M. Fulicin, a Novel Neuropeptide Containing a D-amino Acid Residue Isolated from the Ganglia of Achatina Fulica. Biochem. Biophys. Res. Commun. 1991, 178, 486-493. [CrossRef]

47. Kamatani, Y.; Minakata, H.; Kenny, P.T.M.; Iwashita, T.; Watanabe, K.; Funase, K.; Sun, X.P.; Yongsiri, A.; Kim, K.H.; Novales-Li, P.; et al. Achatin-I, an endogenous neuroexcitatoty tetrapeptide from Achatina fulica ferussac containing a D-amino acid residue. Biochem. Biophys. Res. Commun. 1989, 160, 1015-1020. [CrossRef]

48. Lee, C.J.; Qiu, T.A.; Sweedler, J.V. D-Alanine: Distribution, Origin, Physiological Relevance, and Implications in Disease. Biochim. Biophys. Acta Proteins Proteom. 2020, 1868, 140482-140501. [CrossRef] [PubMed]

49. Ayon, N.J. Features, roles and chiral analyses of proteinogenic amino acids. AIMS Mol. Sci. 2020, 7, 229-268. [CrossRef]

50. Fisher, G.H.; Garcia, N.M.; Payan, I.L.; Cadilla-Perezrios, R.; Sheremata, W.A.; Man, E.H. D-aspartic acid in purified myelin and myelin basic protein. Biochem. Biophys. Res. Commun. 1986, 135, 683-687. [CrossRef]

51. Lee, J.M.; Petrucelli, L.; Fisher, G.; Ramdath, S.; Castillo, J.; Di Fiore, M.; D’Aniello, A. Evidence for D-Aspartyl- $\beta$-Amyloid Secretase Activity in Human Brain. J. Neuropathol. Exp. Neurol. 2002, 61, 125-131. [CrossRef] [PubMed]

52. Hashimoto, A.; Oka, T. Free D-Aspartate and D-Serine in the Mammalian Brain and Periphery. Prog. Neurobiol. 1997, 52, 325-353. [CrossRef]

53. Homma, H. Biochemistry of D-Aspartate in Mammalian Cells. Amino Acids 2007, 32, 3-11. [CrossRef] [PubMed]

54. Topo, E.; Soricelli, A.; D'Aniello, A.; Ronsini, S.; D'Aniello, G. The Role and Molecular Mechanism of D-Aspartic Acid in the Release and Synthesis of LH and Testosterone in Humans and Rats. Reprod. Biol. Endocrinol. 2009, 7, 120-131. [CrossRef] [PubMed]

55. Chung, J.S.; Zmora, N.; Katayama, H.; Tsutsui, N. Crustacean Hyperglycemic Hormone (CHH) Neuropeptidesfamily: Functions, Titer, and Binding to Target Tissues. Gen. Comp. Endocrinol. 2010, 166, 447-454. [CrossRef] [PubMed]

56. Strauch, R.C.; Svedin, E.; Dilkes, B.; Chapple, C.; Li, X. Discovery of a Novel Amino Acid Racemase through Exploration of Natural Variation in Arabidopsis thaliana. Proc. Natl. Acad. Sci. USA 2015, 112, 11726-11731. [CrossRef] [PubMed] 
57. Miyamoto, T.; Moriya, T.; Homma, H.; Oshim, T. Enzymatic Properties and Physiological Function of Glutamate Racemase from Thermus thermophilus. Biochim. Biophys. Acta Proteins Proteom. 2020, 1868, 140461-140467. [CrossRef]

58. Ollivaux, C.; Soyez, D.; Toullec, J.-Y. Biogenesis of D -Amino Acid Containing Peptides/Proteins: Where, When and How? J. Pept. Sci. 2014, 20, 595-612. [CrossRef]

59. Fujii, N.; Momose, Y.; Ishii, N.; Takita, M.; Akaboshi, M.; Kodama, M. The Mechanisms of Simultaneous Stereoinversion, Racemization, and Isomerization at Specific Aspartyl Residues of Aged Lens Proteins. Mech. Ageing. Dev. 1999, 107, 347-358. [CrossRef]

60. Fujii, N.; Sakaue, H.; Sasaki, H.; Fujii, N. A Rapid, Comprehensive Liquid Chromatography-Mass Spectrometry (LC-MS)-based Survey of the Asp Isomers in Crystallins from Human Cataract Lenses. J. Biol. Chem. 2012, 287, 39992-40002. [CrossRef]

61. Mitchell, A.R.; Kent, S.B.H.; Chu, I.C.; Merrifield, R.B. Quantitative Determination of D- and L-amino Acids by Reaction with Tert-Butyloxycarbonyl-L-Leucine N-Hydroxysuccinimide Ester and Chromatographic Separation as L,D and L,L Dipeptides. Anal. Chem. 1978, 50, 637-640. [CrossRef]

62. Yan, L.; Ke, Y.; Kan, Y.; Lin, D.; Yang, J.; He, Y.; Wu, L. New Insight into Enzymatic Hydrolysis of Peptides with Site-Specific Amino Acid d-Isomerization. Bioorg. Chem. 2020, 10, 104389-104399. [CrossRef] [PubMed]

63. Du, S.; Readel, E.R.; Wey, M.; Armstrong, D.W. Complete Identification of All 20 Relevant Epimeric Peptides in $\beta$-Amyloid: A New HPLC-MS Based Analytical Strategy for Alzheimer's Research. Chem. Commun. 2020, 56, 1537-1540. [CrossRef]

64. Takata, T.; Ha, S.; Koide, T.; Fujii, N. Site-Specific Rapid Deamidation and Isomerization in Human Lens AA-crystallin In Vitro. Protein Sci. 2020, 29, 941-951. [CrossRef] [PubMed]

65. Kaiser, K.; Benner, T. Hydrolysis-Induced Racemization of Amino Acids: Hydrolysis-Induced Amino Acid Racemization. Limnol. Oceanogr. Methods 2005, 3, 318-325. [CrossRef]

66. Danielsen, M.; Nebel, C.; Dalsgaard, T.K. Simultaneous Determination of L- and D-amino Acids in Proteins: A Sensitive Method Using Hydrolysis in Deuterated Acid and Liquid Chromatography-Tandem Mass Spectrometry Analysis. Foods 2020, 9, 309. [CrossRef]

67. Manning, J.M. Determination of D- and L-amino Acid Residues in Peptides. Use of Tritiated Hydrochloric Acid to Correct for Racemization during Acid Hydrolysis. J. Am. Chem. Soc. 1970, 92, 7449-7454. [CrossRef] [PubMed]

68. Davankov, V. The Nature of Chiral Recognition: Is It a Three-Point Interaction? Chirality 1997, 9, 99-102. [CrossRef]

69. Yu, L.; Wang, S.; Zeng, S. Chiral Mobile-Phase Additives in HPLC Enantioseparations. In Chiral Separations. Methods and Protocols, 3rd ed.; Scriba, G.K.E., Ed.; Methods in Molecular Biology; Humana: Totowa, NJ, USA; Springer: New York, NY, USA, 2019; pp. 81-91, ISBN 9781493994380.

70. Chankvetadze, B. Recent Trends in Preparation, Investigation and Application of Polysaccharide-Based Chiral Stationary Phases for Separation of Enantiomers in High-Performance Liquid Chromatography. Trends Anal. Chem. 2020, 122, 115709. [CrossRef]

71. Mejía-Carmona, K.; da Silva Burato, J.S.; Borsatto, J.V.B.; de Toffoli, A.L.; Lanças, F.M. Miniaturization of liquid chromatography coupled to mass spectrometry: 1. Current trends on miniaturized LC columns. Trends Anal. Chem. 2020, 122, 115735-115750. [CrossRef]

72. Zhao, Y.; Zhu, X.; Jiang, W.; Liu, H.; Sun, B. Chiral Recognition for Chromatography and Membrane-Based Separations: Recent Developments and Future Prospects. Molecules 2021, 26, 1145. [CrossRef]

73. Okamoto, Y.; Kawashima, M.; Hatada, K. Useful Chiral Packing Materials for High-Performance Liquid Chromatographic Resolution of Enantiomers: Phenylcarbamates of Polysaccharides Coated on Silica Gel. J. Am. Chem. Soc. 1984, 106, 5357-5359. [CrossRef]

74. Lin, Z.; Tai, H.-C.; Zhu, C.; Fabiano, A.; Borges-Muñoz, A.; Ye, Y.K.; He, B.L. Evaluation of a Polysaccharide-Based Chiral Reversed-Phase Liquid Chromatography Screen Strategy in Pharmaceutical Analysis. J. Chromatogr. A 2021, 1645, 462085-462094. [CrossRef]

75. Chankvetadze, B. Polysaccharide-Based Chiral Stationary Phases for Enantioseparations by High-Performance Liquid Chromatography: An Overview. In Chiral Separations, 3rd ed.; Scriba, G.K.E., Ed.; Methods in Molecular Biology; Humana: New York, NY, USA; Springer: New York, NY, USA, 2019; pp. 93-126, ISBN 9781493994380.

76. Mitchell, C.R.; Armstrong, D.W. Cyclodextrin-Based Chiral Stationary Phases for Liquid Chromatography. In Chiral Separation, 1st ed.; Gübitz, G., Schmid, M.G., Eds.; Methods in Molecular Biology; Humana Press: New York, NY, USA, 2004; Volume 243, pp. 31-112, ISBN 9781592596485.

77. Dai, Y.; Wang, S.; Tang, W.; Ng, S.-C. Cyclodextrin-Based Chiral Stationary Phases for High-Performance Liquid Chromatography. In Modified Cyclodextrins for Chiral Separation, 1st ed.; Tang, W., Ng, S.-C., Sun, D., Eds.; Springer: Berlin/Heidelberg, Germany, 2013; pp. 67-101, ISBN 9783642376481.

78. Li, X.; Wang, Y. HPLC Enantioseparation on Cyclodextrin-Based Chiral Stationary Phases. In Chiral Separations, 3rd ed.; Scriba Gerhard, K.E., Ed.; Methods in Molecular Biology; Humana: Totowa, NJ, USA; Springer: New York, NY, USA, 2019; pp. 159-169, ISBN 978-1-4939-9438-0.

79. Shuang, Y.; Liao, Y.; Zhang, T.; Li, L. Preparation and Evaluation of an Ethylenediamine Dicarboxyethyl Diamido-Bridged Bis( $\beta$-Cyclodextrin)-Bonded Chiral Stationary Phase for High Performance Liquid Chromatography. J. Chromatogr. A 2020, 1619, 460937-460947. [CrossRef] [PubMed]

80. Yoshikawa, K.; Furuno, M.; Tanaka, N.; Fukusaki, E. Fast Enantiomeric Separation of Amino Acids Using Liquid Chromatography/Mass Spectrometry on a Chiral Crown Ether Stationary Phase. J. Biosci. Bioeng. 2020, 130, 437-442. [CrossRef] [PubMed] 
81. Upmanis, T.; Kažoka, H.; Arsenyan, P. A Study of Tetrapeptide Enantiomeric Separation on Crown Ether Based Chiral Stationary Phases. J. Chromatogr. A 2020, 1622, 461152-461161. [CrossRef] [PubMed]

82. Nakano, Y.; Taniguchi, M.; Fukusaki, E. High-Sensitive Liquid Chromatography-Tandem Mass Spectrometry-Based Chiral Metabolic Profiling Focusing on Amino Acids and Related Metabolites. J. Biosci. Bioeng. 2019, 127, 520-527. [CrossRef]

83. Carrão, D.B.; Perovani, I.S.; de Albuquerque, N.C.P.; de Oliveira, A.R.M. Enantioseparation of Pesticides: A Critical Review. TrAC Trends Anal. Chem. 2020, 122, 115719-115734. [CrossRef]

84. Teixeira, J.; Tiritan, M.E.; Pinto, M.M.M.; Fernandes, C. Chiral Stationary Phases for Liquid Chromatography: Recent Developments. Molecules 2019, 24, 865. [CrossRef] [PubMed]

85. Fernandes, C.; Phyo, Y.Z.; Silva, A.S.; Tiritan, M.E.; Kijjoa, A.; Pinto, M.M.M. Chiral Stationary Phases Based on Small Molecules: An Update of the Last 17 Years. Sep. Purif. Rev. 2017, 47, 89-123. [CrossRef]

86. Kohout, M.; Hovorka, Š.; Herciková, J.; Wilk, M.; Sysel, P.; Izák, P.; Bartůněk, V.; von Baeckmann, C.; Pícha, J.; Frühauf, P. Evaluation of Silica from Different Vendors as the Solid Support of Anion-exchange Chiral Stationary Phases by Means of Preferential Sorption and Liquid Chromatography. J. Sep. Sci. 2019, 42, 3653-3661. [CrossRef]

87. Hsiao, S.-H.; Ishii, C.; Furusho, A.; Hsieh, C.-L.; Shimizu, Y.; Akito, T.; Mita, M.; Okamura, T.; Konno, R.; Ide, T.; et al. Determination of Phenylalanine Enantiomers in the Plasma and Urine of Mammals and D-amino Acid Oxidase Deficient Rodents Using Two-Dimensional High-Performance Liquid Chromatography. Biochim. Biophys. Acta Proteins Proteom. 2020, 1868, 140540-140547. [CrossRef]

88. Bäurer, S.; Ferri, M.; Carotti, A.; Neubauer, S.; Sardella, R.; Lämmerhofer, M. Mixed-Mode Chromatography Characteristics of Chiralpak ZWIX (+) and ZWIX (-) and Elucidation of Their Chromatographic Orthogonality for LC $\times$ LC Application. Anal. Chim. Acta 2020, 1093, 168-179. [CrossRef]

89. Geibel, C.; Dittrich, K.; Woiwode, U.; Kohout, M.; Zhang, T.; Lindner, W.; Lämmerhofer, M. Evaluation of Superficially Porous Particle Based Zwitterionic Chiral Ion Exchangers against Fully Porous Particle Benchmarks for Enantioselective Ultra-High Performance Liquid Chromatography. J. Chromatogr. A 2019, 1603, 130-140. [CrossRef]

90. Zhu, L.; Zhu, L.; Sun, X.; Wu, Y.; Wang, H.; Cheng, L.; Shen, J.; Ke, Y. Novel Chiral Stationary Phases Based on 3,5-dimethyl Phenylcarbamoylated B-cyclodextrin Combining Cinchona Alkaloid Moiety. Chirality 2020, 32, 1080-1090. [CrossRef]

91. Bajtai, A.; Ilisz, I.; Howan, D.H.O.; Tóth, G.K.; Scriba, G.K.E.; Lindner, W.; Péter, A. Enantioselective Resolution of Biologically Active Dipeptide Analogs by High-Performance Liquid Chromatography Applying Cinchona Alkaloid-Based Ion-Exchanger Chiral Stationary Phases. J. Chromatogr. A 2020, 1611, 460574-460586. [CrossRef] [PubMed]

92. Horak, J.; Lämmerhofer, M. Stereoselective Separation of Underivatized and 6-Aminoquinolyl-N-Hydroxysuccinimidyl Carbamate Derivatized Amino Acids Using Zwitterionic Quinine and Quinidine Type Stationary Phases by Liquid ChromatographyHigh Resolution Mass Spectrometry. J. Chromatogr. A 2019, 1596, 69-78. [CrossRef]

93. Horak, J.; Lämmerhofer, M. Derivatize, Racemize, and Analyze—An Easy and Simple Procedure for Chiral Amino Acid Standard Preparation for Enantioselective Metabolomics. Anal. Chem. 2019, 91, 7679-7689. [CrossRef] [PubMed]

94. Pucciarini, L.; González-Ruiz, V.; Zangari, J.; Martinou, J.-C.; Natalini, B.; Sardella, R.; Rudaz, R. Development and Validation of a Chiral UHPLC-MS Method for the Analysis of Cysteine Enantiomers in Biological Samples. J. Pharm. Biomed. Anal. 2020, 177, 112841-112849. [CrossRef]

95. Seki, T.; Sato, M.; Konno, A.; Hirai, H.; Kurauchi, Y.; Hisatsune, A.; Katsuki, H. D-Cysteine Promotes Dendritic Development in Primary Cultured Cerebellar Purkinje Cells via Hydrogen Sulfide Production. Mol. Cell. Neurosci. 2018, 93, 36-47. [CrossRef] [PubMed]

96. Kimura, R.; Tsujimura, H.; Tsuchiya, M.; Soga, S.; Ota, N.; Tanaka, A.; Kim, H. Development of a Cognitive Function Marker Based on D-amino Acid Proportions Using New Chiral Tandem LC-MS/MS Systems. Sci. Rep. 2020, 10, 804-817. [CrossRef]

97. Kimura, T.; Hesaka, A.; Yoshitaka, I. Utility of D-Serine Monitoring in Kidney Disease. Biochim. Biophys. Acta Proteins Proteom. 2020, 1868, 140449-140454. [CrossRef]

98. Furusho, A.; Koga, R.; Akita, T.; Mita, M.; Kimura, T.; Hamase, K. Three-Dimensional High-Performance Liquid Chromatographic Determination of Asn, Ser, Ala, and Pro Enantiomers in the Plasma of Patients with Chronic Kidney Disease. Anal. Chem. 2019, 18, 11569-11575. [CrossRef] [PubMed]

99. Ilisz, I.; Orosz, T.; Péter, A. High-Performance Liquid Chromatography Enantioseparations Using Macrocyclic GlycopeptideBased Chiral Stationary Phases: An Overview. In Chiral Separations, 3rd ed.; Scriba, G.K.E., Ed.; Methods in Molecular Biology; Humana: New York, NY, USA; Springer: New York, NY, USA, 2019; pp. 201-237, ISBN 9781493994380.

100. Mazzoccanti, G.; Manetto, S.; Ricci, A.; Cabri, W.; Orlandin, A.; Catani, M.; Felletti, S.; Cavazzini, A.; Ye, M.; Ritchie, H.; et al. High-Throughput Enantioseparation of $\mathrm{N} \alpha$-Fluorenylmethoxycarbonyl Proteinogenic Amino Acids through Fast Chiral Chromatography on Zwitterionic-Teicoplanin Stationary Phases. J. Chromatogr. A 2020, 1624, 461235-461246. [CrossRef]

101. West, C. Recent Trends in Chiral Supercritical Fluid Chromatography. Trends Anal. Chem. 2019, 120, 115648-115657. [CrossRef]

102. Kaplitz, A.; Mostafa, M.E.; Calvez, S.A.; Edwards, J.L.; Grinias, J.P. Two-dimensional Separation Techniques Using Supercritical Fluid Chromatography. J. Sep. Sci. 2021, 44, 426-437. [CrossRef]

103. Jakubec, P.; Douša, M.; Nováková, L. Supercritical Fluid Chromatography in Chiral Separations: Evaluation of Equivalency of Polysaccharide Stationary Phases. J. Sep. Sci. 2020, 43, 2675-2689. [CrossRef] [PubMed] 
104. Lipka, E.; Dascalu, A.-E.; Messara, Y.; Tsutsqiridze, E.; Farkas, T.; Chankvetadze, B. Separation of Enantiomers of Native Amino Acids with Polysaccharide-Based Chiral Columns in Supercritical Fluid Chromatography. J. Chromatogr. A 2019, 1585, $207-212$. [CrossRef]

105. Miller, L.; Yue, L. Chiral Separation of Underivatized Amino Acids in Supercritical Fluid Chromatography with Chiral Crown Ether Derived Column. Chirality 2020, 32, 981-989. [CrossRef] [PubMed]

106. Schurig, V. Gas Chromatographic Enantioseparation of Derivatized $\alpha$-Amino Acids on Chiral Stationary Phases-Past and Present. J. Chromatogr. B 2011, 879, 3122-3140. [CrossRef] [PubMed]

107. Xie, S.-M.; Chen, X.-X.; Zhang, J.-H.; Yuan, L.-M. Gas Chromatographic Separation of Enantiomers on Novel Chiral Stationary Phases. Trends Anal. Chem. 2020, 124, 115808-115828. [CrossRef]

108. Yu, R.B.; Quirino, J.P. Chiral Selectors in Capillary Electrophoresis: Trends during 2017-2018. Molecules 2019, 24, 1135. [CrossRef] [PubMed]

109. Koster, N.; Clark, C.P.; Kohler, I. Past, Present, and Future Developments in Enantioselective Analysis Using Capillary Electromigration Techniques. Electrophoresis 2021, 42, 38-57. [CrossRef]

110. Konjaria, M.-L.; Scriba, G.K.E. Enantioseparation of Analogs of the Dipeptide Alanyl-Phenylalanine by Capillary Electrophoresis Using Neutral Cyclodextrins as Chiral Selectors. J. Chromatogr. A 2020, 1623, 461158-461165. [CrossRef]

111. Konjaria, M.-L.; Scriba, G.K.E. Enantioseparation of Alanyl-Phenylalanine Analogs by Capillary Electrophoresis Using Negatively Charged Cyclodextrins as Chiral Selectors. J. Chromatogr. A 2020, 1632, 461585. [CrossRef] [PubMed]

112. Greño, M.; Castro-Puyana, M.; Marina, M.L. Enantiomeric Separation of Homocysteine and Cysteine by Electrokinetic Chromatography Using Mixtures of $\gamma$-Cyclodextrin and Carnitine-Based Ionic Liquids. Microchem. J. 2020, 157, 105070-105078. [CrossRef]

113. Zhang, Y.; Hu, X.; Wang, Q.; He, P. Investigation of Hydroxypropyl- $\beta$-Cyclodextrin-Based Synergistic System with Chiral Nematic Mesoporous Silica as Chiral Stationary Phase for Enantiomeric Separation in Microchip Electrophoresis. Talanta 2020, 218, 121121-121128. [CrossRef] [PubMed]

114. Lee, S.; Kim, S.-J.; Bang, E.; Na, Y.-C. Chiral Separation of Intact Amino Acids by Capillary Electrophoresis-Mass Spectrometry Employing a Partial Filling Technique with a Crown Ether Carboxylic Acid. J. Chromatogr. A 2019, 1586, 128-138. [CrossRef]

115. Liu, L.; Bao, P.; Qiao, J.; Zhang, H.; Qi, L. Chiral Ligand Exchange Capillary Electrophoresis with L-Dipeptides as Chiral Ligands for Separation of Dns-D,L-amino Acids. Talanta 2020, 217, 121069-121075. [CrossRef]

116. Feng, W.; Qiao, J.; Li, D.; Qi, L. Chiral Ligand Exchange Capillary Electrochromatography with Dual Ligands for Enantioseparation of D, L-amino Acids. Talanta 2019, 194, 430-436. [CrossRef]

117. Xu, Z.; Guan, J.; Shao, H.; Fan, S.; Li, X.; Shi, S.; Yan, F. Combined Use of Cu(II)-L-Histidine Complex and $\beta$-Cyclodextrin for the Enantioseparation of Three Amino Acids by CE and a Study of the Synergistic Effect. J. Chromatogr. Sci. 2020, 58, 969-975. [CrossRef]

118. Evans, K.; Wang, X.; Roper, M.G. Chiral micellar electrokinetic chromatographic separation for determination of L- and D-primary amines released from murine islets of Langerhans. Anal. Methods 2019, 11, 1276-1283. [CrossRef]

119. Moldovan, R.-C.; Bodoki, E.; Servais, A.-C.; Crommen, J.; Oprean, R.; Fillet, M. Selectivity Evaluation of Phenyl Based Stationary Phases for the Analysis of Amino Acid Diastereomers by Liquid Chromatography Coupled with Mass Spectrometry. J. Chromatogr. A 2019, 1590, 80-87. [CrossRef]

120. Pérez-Míguez, R.; Bruyneel, B.; Castro-Puyana, M.; Marina, M.L.; Somsen, G.W.; Domínguez-Vega, E. Chiral Discrimination of DL-amino Acids by Trapped Ion Mobility Spectrometry after Derivatization with (+)-1-(9-Fluorenyl)Ethyl Chloroformate. Anal. Chem. 2019, 91, 3277-3285. [CrossRef]

121. Goto, J.; Goto, N.; Nambara, T. New Type of Derivatisation Reagents for Liquid Chromatographic Resolution of Enantiomeric Hydroxyl Compounds. Chem. Pharm. Bull. 1982, 30, 4597-4599. [CrossRef]

122. Miyano, S.; Okada, S.-I.; Hotta, H.; Takeda, M.; Kabuto, C.; Hashimoto, H. Optical Resolution of 2'-Methoxy-1,1'-Binaphthyl2-Carboxylic Acid, and Application to Chiral Derivatizing Agent for HPLC Separation of Enantiomeric Alcohols and Amines. Bull. Chem. Soc. Jpn. 1989, 62, 1528-2533. [CrossRef]

123. Harada, M.; Karakawa, S.; Yamada, N.; Miyano, H.; Shimbo, K. Biaryl Axially Chiral Derivatizing Agent for Simultaneous Separation and Sensitive Detection of Proteinogenic Amino Acid Enantiomers Using Liquid Chromatography-Tandem Mass Spectrometry. J. Chromatogr. A 2019, 1593, 91-101. [CrossRef] [PubMed]

124. Harada, M.; Karakawa, S.; Miyano, H.; Shimbo, K. Simultaneous Analysis of d,L-amino Acids in Human Urine Using a ChiralitySwitchable Biaryl Axial Tag and Liquid Chromatography Electrospray Ionization Tandem Mass Spectrometry. Symmetry 2020, 12, 913. [CrossRef]

125. Han, Y.; Jin, M.-N.; Xu, C.-Y.; Qian, Q.; Nan, J.; Jin, T.; Min, J.Z. Evaluation of Chiral Separation Efficiency of a Novel OTPTHE Derivatization Reagent: Applications to Liquid-chromatographic Determination of DL-serine in Human Plasma. Chirality 2019, 31, 1043-1052. [CrossRef]

126. Russo, M.S.T.; Napylov, A.; Paquet, A.; Vuckovic, D. Comparison of N-Ethyl Maleimide and N-(1-Phenylethyl) Maleimide for Derivatization of Biological Thiols Using Liquid Chromatography-Mass Spectrometry. Anal. Bioanal. Chem. 2020, 412, 1639-1652. [CrossRef] 